\title{
Reinforcement of cell junctions correlates with the absence of hair cell regeneration in mammals and its occurrence in birds
}

\author{
Joseph Burns ${ }^{*}, 1,2$, J. Jared Christophel ${ }^{*}, 3$, Maria Sol Collado ${ }^{2}$, Christopher Magnus $^{2}$, \\ Matthew Carfrae ${ }^{3}$, and Jeffrey T. Corwin ${ }^{2}$ \\ ${ }^{1}$ Department of Biomedical Engineering University of Virginia, School of Engineering and Applied \\ Science Charlottesville, VA 22908 U.S.A. \\ ${ }^{2}$ Department of Neuroscience University of Virginia, School of Medicine Charlottesville, VA 22908 \\ U.S.A. \\ ${ }^{3}$ Department of Otolaryngology - Head and Neck Surgery University of Virginia Health System \\ Charlottesville, VA 22908 U.S.A.
}

\begin{abstract}
Debilitating hearing and balance deficits often arise through damage to the inner ear's hair cells. For humans and other mammals, such deficits are permanent, but non-mammalian vertebrates can quickly recover hearing and balance through their innate capacity to regenerate hair cells. The biological basis for this difference has remained unknown, but recent investigations in wounded balance epithelia have shown that proliferation follows cellular spreading at sites of injury. As mammalian ears mature during the first weeks after birth, the capacity for spreading and proliferation declines sharply. In seeking the basis for those declines, we investigated the circumferential bands of F-actin that bracket the apical junctions between supporting cells in the gravity-sensitive utricle. We found that those bands grow much thicker as mice and humans mature postnatally, while their counterparts in chickens remain thin from hatching through adulthood. When we cultured utricular epithelia from chickens, we found that cellular spreading and proliferation both continued at high levels, even in the epithelia from adults. In contrast, the substantial reinforcement of the circumferential F-actin bands in mammals coincides with the steep declines in cell spreading and production established in earlier experiments. We propose that the presence of thin F-actin bands at the junctions between avian supporting cells may contribute to the lifelong persistence of their capacity for shape change, cell proliferation, and hair cell replacement, while the postnatal reinforcement of the F-actin bands in maturing humans and other mammals may have an important role in limiting hair cell regeneration.
\end{abstract}

\section{Keywords}

ear; repair; balance; vestibular; proliferation; actin

\section{INTRODUCTION}

Humans and other mammals are vulnerable to permanent deficits of hearing and balance that arise when hair cells are killed by loud sounds, drugs, infections, and other causes, while fish, amphibians, reptiles, and birds can regenerate hair cells and recover sensory function

To whom correspondence should be addressed: Joseph Burns HSC Box 801392 UVA School of Medicine 409 Lane Rd. Extended Charlottesville, VA 22908-1392 Ph: 434-924-8364 Fax: 434-982-3966 Email: jcb7j@ virginia.edu.

These authors contributed equally. 
after supporting cells give rise to replacement hair cells (reviewed in, Meyers and Corwin, 2008). In mammalian embryos, supporting cells can produce replacement hair cells in the organ of Corti (Kelley et al., 1993; White et al., 2006), but their counterparts in postembryonic ears exhibit a high degree of cytoskeletal differentiation (Slepecky and Chamberlain, 1983, 1986; Raphael et al., 1993, 1994; Kuhn and Vater, 1996; Leonova and Raphael, 1997), which may limit their capacity for hair cell replacement.

Less specialized supporting cells in the balance organs of mammalian ears may hold a greater potential for regeneration since adult human utricles that were treated to kill hair cells and then cultured with $\mathrm{H}^{3}$-thymidine were each found to contain at least 100 labeled supporting cells (Warchol et al., 1993). Also, small hair bundles like those that are characteristic of new hair cells have been found in the balance organs of adult rodents (Lambert et al., 1997). When balance epithelia from newborn rodents are isolated and cultured with appropriate mitogens, the majority of the supporting cells begin to proliferate (Zheng et al., 1997, 1998; Gu et al., 1996, 1997, 2007; Montcouquiol and Corwin, 2001a, 2001b). But a sharp, early postnatal decline in cell production capacity follows and appears to leave the mammalian ear uniquely vulnerable to permanent hair cell loss (Gu et al., 1997, 2007).

The propensity for supporting cells to change from a columnar to a spread shape after an injury to the epithelium also declines during the first weeks after birth (Davies et al., 2007; Meyers and Corwin, 2007). This may be significant because the columnar-to-spread cellular shape changes occur hours before S-phase entry and are highly correlated with the probability that an individual supporting cell will enter S-phase (Meyers and Corwin, 2007). Preliminary observations revealed that circumferential F-actin bands at the junctions between these supporting cells grow considerably thicker in murine utricles at some point between E18 and maturity (Meyers and Corwin, 2007), so we set out to investigate when and how that growth occurs and whether it correlates with the early postnatal declines in cellular spreading and proliferation that are unique to mammals.

Using confocal light microscopy and transmission electron microscopy to investigate utricular supporting cells at late embryonic through adult stages, we observed that the circumferential F-actin bands in mice and humans grow much thicker as vestibular supporting cells mature postnatally, while their counterparts in chickens remain thin from hatching through adulthood. When we cultured utricular epithelia from chickens of various ages, they exhibited high levels of cellular spreading and proliferation that also remained nearly the same from hatching to adulthood. Evidence from our investigation suggests that reinforcement of the F-actin bands in mammals is likely to impede the capacity for supporting cells to change from columnar to spread shapes and then proliferate in wounded vestibular epithelia. The results also suggest that the unique reinforcement of the F-actin bands that develops during the early postnatal maturation of mammalian supporting cells may contribute to the permanence of hair cell deficits in humans and other mammals.

\section{MATERIALS AND METHODS}

All animals were handled in accordance with protocols approved by the Animal Care and Use Committee at the University of Virginia. Swiss Webster Mice were obtained from Taconic Farms (Germantown, NY) and Charles River Labs (Wilmington, MA). White Leghorn chickens and fertilized eggs were obtained from CBT Farms (Chestertown, MD), Spafas Inc. (North Franklin, CT), and Slonaker Farm (Glengary, WV) and were incubated to hatching or raised to the specific ages listed in the Results. 


\section{Transmission Electron Microscopy}

Female Swiss Webster mice ranging in age from embryonic day 18 (E18) to postnatal day 83 (P83) and White Leghorn chickens ranging in age from the day of hatching (P0) to oneyear-old (P365) were killed by carbon dioxide asphyxiation and decapitated. The right utricle was fixed for Transmission Electron Microscopy (TEM) as described below, and the left utricle was fixed for confocal microscopy in the majority of the specimens, but both ears were fixed for confocal microscopy in some specimens.

For TEM fixation, a solution of $3 \%$ glutaraldehyde in $0.15 \mathrm{M}$ sodium cacodylate buffer at $\mathrm{pH}$ 7.4 and room temperature (RT) was injected into a hole made in the right superior semicircular canal to replace the endolymphatic fluid. This was accomplished within 3 minutes of the time of death. The labyrinth was then isolated and immersed in a large volume of that fixative overnight at $4^{\circ} \mathrm{C}$. The utricle was later dissected from the labyrinth in $0.15 \mathrm{M}$ cacodylate buffer and postfixed in $1 \%$ osmium-tetroxide followed by dehydration in a graded ethanol series and infiltration with Epon 812 (Electron Microscopy Sciences, Hatfield, PA). Thin sections were cut with a diamond knife, collected on copper grids, and stained with lead citrate for $5 \mathrm{~min}$, followed by uranyl acetate for $15 \mathrm{~min}$, and lead citrate again for $5 \mathrm{~min}$.

The thin sections of a number of specimens were cut parallel to the long axis of the cells in the utricular epithelium and are referred to here as longitudinal sections. Others were cut transverse to that axis and are referred to as transverse sections. All were analyzed in a JEOL 1230 transmission electron microscope equipped with a 16 megapixel slow scan digital camera (Scientific Instruments and Applications Inc., Atlanta, GA), and images were captured at 2500x, 5000x, and 10,000x magnifications. Image contrast and brightness were modified in Adobe Photoshop.

To measure the space between the membranes of neighboring supporting cells at the adherens junction, we counted the pixels that spanned the extracellular space and converted the number of pixels to distance. Five measurements at the adherens junction were averaged to determine the width for a junction, and this process was repeated for $\geq 20$ junctions per age group. This pixel counting method also was used to measure the widths of apical junction regions (AJRs) in the electron microscope images from transverse sections and the vertical dimensions of the circumferential F-actin bands in the longitudinal sections. One to two utricles in each of four age groups were used for longitudinal sections, and one utricle per age group was used for transverse sections because of the difficulty of producing sections with that orientation.

\section{Confocal microscopy}

Immediately after the right ear was fixed for TEM, the left utricle was dissected in DMEM/ F12 (Invitrogen, Carlsbad, CA), the attached ampullae and utricular roof were removed, and the utricle was then immersed in Protease XXIV (Sigma-Aldrich, St. Louis, MO) at $0.1 \mathrm{mg} /$ $\mathrm{ml}$ in DMEM/F12 for 20 minutes at RT. The otoconia were removed in DMEM/F12 using the flow from a fire-polished glass pipette. Then the utricle was fixed in fresh $4 \%$ paraformaldehyde in $0.15 \mathrm{M}$ phosphate buffer (PB) at $\mathrm{pH} 7.4$ for $1 \mathrm{hr}$ at $\mathrm{RT}$ or overnight at $4^{\circ} \mathrm{C}$.

The fixed utricles were washed in phosphate buffered saline (PBS), then incubated for 45 minutes in PBS plus $0.2 \%$ Triton X-100 (PBS-T) and AlexaFluor 488-phalloidin (5 units/ml; Invitrogen). The whole mount utricles were then washed in PBS, mounted in Slow Fade (Invitrogen), and analyzed using a Zeiss LSM 510 laser scanning confocal microscope. Image contrast and brightness were modified in Adobe Photoshop. 
For N-cadherin immunohistochemistry, whole mount utricles were immersed in $1 \%$ Triton $\mathrm{X}-100$ in PEM buffer (100 mM Pipes, pH 6.9, $1 \mathrm{mM} \mathrm{MgCl}_{2}$, and $1 \mathrm{mM}$ EGTA) containing $4 \%$ polyethylene glycol (PEG), mol wt 40,000 (Serva, Heidelberg, Germany) and $0.5 \mathrm{mM}$ AlexFluor 488-phalloidin for 10 minutes at RT to extract membrane lipids (Svitkina and Borisy, 1998). After the extraction, the utricles were washed briefly with the phalloidincontaining PEM buffer and fixed in 4\% paraformaldehyde in $0.15 \mathrm{M} \mathrm{PB}$ at $\mathrm{pH} 7.4$ for $1 \mathrm{hr}$ at RT or overnight at $4^{\circ} \mathrm{C}$. Then the utricles were washed in PBS and pre-incubated for $1 \mathrm{hr}$ at RT in PBS-T containing 10\% normal goat serum (NGS; Vector Laboratories, Burlingame, CA). Next they were incubated in 1:50 rat anti-mouse N-cadherin (MNCD2; Developmental Studies Hybridoma Bank, University of Iowa) in PBS-T with $2 \%$ NGS overnight at $4^{\circ} \mathrm{C}$.

After incubation with the primary antibody, the utricles were washed in PBS-T and incubated in 1:200 AlexaFluor 546 goat anti-rat $\operatorname{IgG}(\mathrm{H}+\mathrm{L})(2 \mathrm{mg} / \mathrm{ml}$; Invitrogen) for $1 \mathrm{hr}$ at RT. The utricles were then washed in PBS and mounted in Slow Fade for analysis using the confocal microscope.

\section{Culture of the sensory epithelia}

For tissue culture, White Leghorn chickens from the day of hatching to 420-days-old (P420) were killed by carbon dioxide asphyxiation and decapitated. To allow such a wide range of ages to be investigated, chickens had to be obtained from two different suppliers. The skin was removed from the head, which was immersed immediately in ice-cold $70 \%$ ethanol for 10 to 20 minutes. Under aseptic conditions, the heads were transferred to ice-cold Medium 199 with Hanks salts (M199) (Life Technologies, Gaithersburg, MD) and bisected at the midline. Each utricle was dissected, and the otoconia, otolithic membrane, and portions of the surrounding non-sensory epithelium were removed. The utricles were then incubated in thermolysin $\left(0.5 \mathrm{mg} / \mathrm{ml}\right.$; Sigma) at $37^{\circ} \mathrm{C}$ and $5 \% \mathrm{CO}_{2}$ for $12-20$ minutes, with those from older animals requiring the longer incubation times. Then the utricles were transferred to M199 containing 5\% fetal bovine serum, and the epithelium of each utricle was separated from the underlying tissue using fine forceps. The non-sensory epithelium was then cut away with a sapphire scalpel and discarded, and the remaining sheet of pure sensory epithelium was cut into 9-12 square sheets of approximately equal area. 4-5 sheets were transferred into each poly-d-lysine-coated, glass-bottom culture dish (MatTek, Ashland, MA) that had been prepared by inserting custom-made, $0.4 \mathrm{~mm}$ thick silicone gaskets and coating the glass-bottom well within the gasket with fibronectin (FN, Sigma) at $100 \mu \mathrm{g} / \mathrm{ml}$ overnight.

Special care was taken to orient the sheets of sensory epithelium with their hair bundles up. Then a circular coverglass was placed over the gasket in each dish, and the dishes were centrifuged at $200 \mathrm{~g}$ for 5 minutes at $4^{\circ} \mathrm{C}$ in a Beckman TJ4 or Eppendorf $5810 \mathrm{R}$ centrifuge to promote adhesion of the sensory epithelia to the dish. After centrifugation, the entire central well of each dish was filled with the culture medium, the circular coverglass was carefully removed, and the dishes containing the attached sensory epithelia were cultured at $37^{\circ} \mathrm{C}$ in $5 \% \mathrm{CO}_{2}$.

A subset of the cultures from the P0 and P180 chickens were cultured in M-199, 10\% FBS, and $3 \mu \mathrm{g} / \mathrm{ml}$ Bromodeoxyuridine (BrdU; Sigma) that also contained the DNA polymerase inhibitor, aphidicolin (Sigma), at $25 \mu \mathrm{M}$ for the entire 72-hr culture period.

\section{Measurements of epithelial spreading}

Images of the individual sheets of sensory epithelium were captured at 1, 24, 48 and $72 \mathrm{hr}$ after plating. At each time point, the outline of each sheet was traced, and the area was measured using ImageJ or MetaMorph software (Universal Imaging, Media, PA). To normalize for slight differences in the starting sizes of the explanted sheets of epithelia, the 
areas of the explants at 24,48 , and $72 \mathrm{hr}$ were expressed as fold increases relative to the first area measurement from the image of that sheet captured after $1 \mathrm{hr}$ of incubation.

\section{Measurements of S-phase entry}

To label cells that entered S-phase, $3 \mu \mathrm{g} / \mathrm{ml} \mathrm{BrdU}$ was added to the cultures $2 \mathrm{hr}$ before the end of the $72 \mathrm{hr}$ culture period. The cultures were rinsed with PBS, fixed in 4\% paraformaldehyde in PBS for 15 minutes at RT, and rinsed 3 times with PBS. DNA that incorporated BrdU was visualized by immunostaining as previously described (Montcouquiol and Corwin, 2001a). Briefly, epithelia were incubated in $1 \mathrm{~N} \mathrm{HCL}$ for 15 minutes to denature nucleic acids. BrdU was detected using a mouse monoclonal anti-BrdU (1:50; BD Biosciences \# 347580, San Jose, CA), a biotinylated rat-adsorbed anti-mouse IgG secondary antibody (Vector Laboratories, Burlingame, CA), and an Elite avidin-biotin complex (ABC) kit with nickel intensification (Vector Laboratories). BrdU-negative nuclei were visualized by their fluorescence after counterstaining in $10 \mu \mathrm{g} / \mathrm{mL}$ DAPI. After three rinses with PBS, the specimens were mounted in SlowFade and differential interference contrast (DIC) and epifluorescence images were captured using an inverted microscope and a cooled CCD camera.

The BrdU-positive and the DAPI-stained, BrdU-negative nuclei in each explant were counted using a manual method to ensure accuracy. For this, acetate sheets were marked so that each contained a grid of $100 \mu \mathrm{m} \times 100 \mu \mathrm{m}$ squares calibrated to the microscope system. Then an acetate sheet was centered on a printed DIC image of each explanted sheet of sensory epithelium, and it was rotated to maximize the number of complete squares superimposed on the image of the sensory epithelium. The BrdU-positive nuclei were counted in eight squares distributed radially at $45^{\circ}$ intervals, and the acetate sheet was marked so that it could be oriented in register after it was moved to the printed fluorescent image for counting the DAPI-stained nuclei in the same eight squares. The counts of DAPI and BrdU-positive nuclei were used to calculate the percentage of the nuclei that were BrdU-positive in each sheet of cultured sensory epithelium.

For experiments used to check the efficacy of aphidicolin in blocking proliferation, fixed cultures were incubated at $37^{\circ} \mathrm{C}$ in DNase I (100 kunitz units in $100 \mu \mathrm{l}$ of PBS with $4 \mathrm{mM}$ $\mathrm{MgCl}_{2} ;$ Sigma) and immunostained using the mouse monoclonal anti-BrdU (1:50; BD Biosciences) and an Alexa-546 anti-mouse IgG secondary antibody (Invitrogen). Then the labelled epithelia were analyzed using a Zeiss LSM 510 laser scanning confocal microscope.

\section{Antibody Characterization}

The $\mathrm{N}$-cadherin antibody used had been generated as a monoclonal against a peptide encoding amino acids 308-587 of N-cadherin as described elsewhere (Matsunami and Takeichi, 1995). In immunoblots of mouse fetal brains, that antibody has been shown to bind with high affinity for a band at or near to N-cadherin's molecular weight of $135 \mathrm{kDa}$ (Matsunami and Takeichi, 1995). This antibody gave a similar staining to that seen in mouse vestibular epithelia with a monoclonal antibody directed against E-cadherin (Kim et al., 2005 ) and in chicken vestibular epithelia with a monoclonal antibody directed against $\mathrm{N}$ cadherin (Warchol, 2007).

The monclonal BrdU antibody was generated from clone B44, derived from the hybridization of mouse Sp2/0-Ag14 myeloma cells with spleen cells from Balb/c mice immunized with iodouridine-conjugated ovalbumin. In immunohistochemistry, this commercially available antibody specifically recognizes BrdU-incorporated into DNA (Gratzner, 1982), and it has been shown to label BrdU-incorporated into DNA in supporting cells in the utricles of mice (Davies et al., 2007, Meyers and Corwin, 2007), rats 
(Montcouquiol and Corwin, 2001a; 2001b; Gu et al., 2007), humans, and guinea pigs (Warchol et al., 1993), and in the basilar papillae and utricles of chickens (Warchol and Corwin, 1996; Witte et al. 2001).

\section{RESULTS}

\section{Circumferential F-actin bands in vestibular epithelia grow much thicker as mice mature}

When the vestibular epithelia from newborn rodents are damaged or are dissected out and explanted on culture dishes, the supporting cells at the cut edges quickly change from the tall columnar shapes they maintain in intact sensory epithelia to thin and widely spread shapes that extend outward from those edges (Gu et al., 1996, 1997, 2007; Meyers and Corwin, 2007). When such epithelia are cultured in the presence of appropriate growth factors, the majority of the thin, spread supporting cells will subsequently enter S-phase and proliferate, but their initial propensities for changing shape and proliferating decline sharply in the first weeks after birth (Gu et al., 1996, 1997, 2007; Zheng et al., 1998; Montcouquiol and Corwin, 2001a, 2001b). Preliminary observations in our preceding study of murine vestibular epithelia showed that the circumferential F-actin bands that are near the apical junctions between the supporting cells increase in width at some point between E18 and P17, suggesting that the thickness of those bands might be inversely correlated with the capacity for cell shape change and proliferation (Meyers and Corwin, 2007). Therefore, we sought to investigate that growth and determine whether its time course coincided with the declines in cellular spreading and proliferation.

We used fluorescently conjugated phalloidin to label filamentous actin (F-actin) in the utricles of mice in thirteen sample groups that ranged in age from E18 to P83 and observed a substantial increase in the width of the F-actin bands as mice matured from late embryonic (E18), through early postnatal (P8), to adult (P83) stages (Fig. 1A-I). At E18, the gap between the thin F-actin bands on the two sides of supporting cell-supporting cell junctions was not resolved, but it was resolvable at P2 and older ages. At P83, the width of the F-actin bands had increased so significantly that they extended far into the cells, leaving only small central regions of open cytoplasm, which are visible as dark circular patches (Fig. 1F,I). Immunostaining localizes $\mathrm{N}$-cadherin to the gap between the F-actin bands, confirming they are at the level of the adherens junction (Fig. 2A-C).

In contrast to the substantial growth within the supporting cells of the sensory epithelium, the circumferential F-actin bands in the cells of the surrounding nonsensory epithelium appeared to grow only slightly between late embryonic and adult stages (Fig.1A-C, 2D-F).

\section{Growth of the circumferential F-actin bands in mice}

To quantitatively assess the growth of the F-actin bands, we captured confocal images and measured the widths of regions comprised of the intercellular junction between epithelial cells and the F-actin bands on the two sides of the junction, which we refer to as apical junction regions (AJRs; Fig. 3A-C). Such measurements actually assess apparent width because they are limited by the spread of fluorescent emission, but they provide an accurate measurement of the changes in apparent width. LSM 510 software was used to make maximum intensity z-projections from stacks of images extending $5 \mu \mathrm{m}$ above and $5 \mu \mathrm{m}$ below the circumferential F-actin bands in the utricular sensory epithelia, and a semiautomated approach described in Fig. 3 was used to measure the widths of 300 to 400 AJRs in each of the thirteen age groups (Table 1).

We tested the fit of the data using over 25 exponential and power law growth curves and selected a von Bertalanffy growth equation based on its strong fit and widespread 
application for modeling biological growth. The standard von Bertalanffy growth equation is:

$$
\mathrm{W}=\mathrm{W}_{\infty}\left[1-\mathrm{e}^{-\mathrm{k}\left(\mathrm{t}-\mathrm{t}_{0}\right)}\right]
$$

where $\mathrm{W}$ is the AJR width, $\mathrm{W}_{\infty}$ is the AJR width as time approaches infinity, $\mathrm{t}$ is the current time in days, $\mathrm{k}$ is the curvature parameter, and $\mathrm{t}_{0}$ is the initial time. The modified von Bertalanffy growth equation used here is:

$$
\mathrm{W}=\mathrm{W}_{\infty}\left[1-\mathrm{Ce}^{-\mathrm{k}(\mathrm{t}+4)}\right]
$$

where $\mathrm{C}$ is a scaling factor included to prevent the width from equaling zero at the initial time, and the initial time, $\mathrm{t}_{0}$, is set to -4 to represent embryonic day 18 , the initial time point in the data collection (Fig. 4).

As mice developed between E18 and P10, the average width of the AJRs in the sensory epithelium increased by $\sim 110 \mathrm{~nm}$ per day, yielding a $\sim 200 \%$ increase in width (Fig. 4). By about two to three weeks after birth, the growth in the width of the AJRs slowed to $\sim 21 \mathrm{~nm}$ per day, so that the cumulative result was a $\sim 400 \%$ increase in width from E18 to P83. The early rapid increase in width appears to coincide with the time when these supporting cells lose the ability to spread and proliferate.

For comparison, we measured the widths of 300 to 400 AJRs in the nonsensory epithelium that surrounds the utricle's sensory macula in each of six age groups ranging from E18 to P83 (Table 1). We defined the boundary of the nonsensory epithelium as the region nearest to the periphery of the sensory epithelium which contained at least 30 contiguous epithelial cells within which there were no cells containing cuticular plates or hair bundles. As mice developed from E18 to P10, AJR widths in the nonsensory epithelium increased by $\sim 15 \mathrm{~nm} /$ day, slowing to $\sim 2 \mathrm{~nm} /$ day from P10 to P83 (Fig. 4). Between E18 and P10, the cumulative increase was $\sim 25 \%$, and from E18 to P83, the total increase in width was $\sim 58 \%$. Thus, as mice develop and mature, the AJRs that are shared between neighboring utricular supporting cells grow much wider, while the equivalent structures in the surrounding nonsensory epithelium exhibit only modest growth.

\section{The increases in AJR width result from growth of the F-actin bands}

We used transmission electron microscopy (TEM) to determine whether a significant portion of the growth in the AJRs was due to increased extracellular junctional space. In longitudinal sections cut parallel to the long axis of cells in the epithelia, the width of the extracellular space at supporting cell-supporting cell adherens junctions averaged $26 \pm 7.5$ $\mathrm{nm}$ at E18, $25.4 \pm 7.7 \mathrm{~nm}$ at P5, $23.7 \pm 9.9 \mathrm{~nm}$ at P12, $24.3 \pm 4.7 \mathrm{~nm}$ at P52 $(\mathrm{n} \geq 20$ junctions per age group), and $24.9 \pm 1 \mathrm{~nm}$ for all four ages. In transverse sections, the width averaged $24.5 \pm 5.0 \mathrm{~nm}$ at E18, $22.6 \pm 5.8 \mathrm{~nm}$ at P52 ( $\mathrm{n} \geq 20$ junctions per age group), and $23.6 \pm 1.3 \mathrm{~nm}$ for the two ages. The results show that the extracellular space across the junctions does not change appreciably as mice mature, so that the increases in AJR width measured in confocal microscopy are attributable to growth of the circumferential F-actin bands.

Using TEM images of the longitudinal sections, we were able to determine the vertical dimensions of the F-actin bands in supporting cells, which are distinguishable as electron dense regions adjacent to the adherens junctions (Hirokawa and Tilney, 1982). The distances 
those electron dense regions (Fig. 5A-D) extended in a direction parallel to the cell's lateral membrane averaged $0.66 \pm 0.19 \mu \mathrm{m}$ at $\mathrm{E} 18,1.13 \pm 0.2 \mu \mathrm{m}$ at P5, $1.43 \pm 0.26 \mu \mathrm{m}$ at P12, and $2.1 \pm 0.62 \mu \mathrm{m}$ at P52 ( $\mathrm{n} \geq 20$ cells per age group). Our measurements of AJR widths in TEM images from transverse sections closely matched the measurements from confocal microscopy, averaging $0.85 \pm 0.21 \mu \mathrm{m}$ at E18 and $3.45 \pm 1.3 \mu \mathrm{m}$ at P52 ( $\geq 30$ AJRs).

We used the measurements of the F-actin bands' widths and vertical dimensions from the mice of different ages to calculate the area of ellipses as rough approximations to the crosssectional areas of the circumferential bands in supporting cells. For the E18 utricles, the approximate cross-sectional area of the circumferential F-actin bands averaged $0.214 \mu^{2}$, while those in P52 utricles averaged $2.83 \mu \mathrm{m}^{2}$, indicating that their cross-sectional area increased $\sim 13.2$-fold between those ages.

ImageJ analysis of the transverse TEM images (Fig. 5E,F) showed that the circumferential F-actin bands occupied $\sim 38 \%$ of the average supporting cell's internal area at the level of the adherens junction in E18 mice, but grew to occupy $\sim 89 \%$ by the time that mice were 52 days old, leaving just $\sim 11 \%$ of the cell area open at that level ( $n \geq 10$ cells). Those images also appear to show periodic regions where the F-actin bands come into close proximity with the membranes of the supporting cells at the level of the adherens junction at both ages (Fig. 5E,F). In P52 mice utricles, the inner accumulations of F-actin in these bands appear to form a structure that is considerably more complex than in the simple bands in the E18 utricles. Small regions of open cytoplasm are interspersed with the electron dense bands of F-actin in the P52 mouse supporting cells, and vesicles are visible in those regions (arrowheads, Fig. 5F), suggesting that the inward growth of the F-actin bands may not prevent normal transport. The TEM images we have obtained thus far have not allowed us to draw conclusions about the regularity, directionality, or packing of the actin filaments in these bands, nor do they reveal whether the F-actin is organized in bundles or branched networks.

To determine whether the circumferential F-actin bands within the supporting cells in the other balance organs of the mouse ear grow thicker with age, we used fluorescentlyconjugated phalloidin and confocal microscopy to investigate the semicircular canals and saccules of P120 mice. While preliminary, analysis of those specimens suggests that the circumferential F-actin bands in the supporting cells of all the balance organs in the ears of mice exhibit age-related growth like that we have measured for utricles (Fig. 11D).

\section{In chicken utricles, the circumferential bands are narrow even in adults}

Cellular spreading and proliferation are limited in mature mammals, but the supporting cells in birds are able to proliferate and replace lost hair cells throughout life (Corwin and Cotanche, 1988; Jorgensen and Mathiessen, 1988; Ryals and Rubel, 1988), so we investigated the circumferential F-actin bands and the levels of cellular spreading and proliferation in utricles from hatchling and adult chickens for comparison with their mammalian counterparts. White Leghorn chickens reach sexual maturity 120 to 190 days after hatching (Dunnington and Siegel, 1984), so we used the same methods as for mice to measure AJR widths in confocal images of phalloidin-labeled utricles from five age groups that ranged from P0 to P365, which spanned the chick, pullet, and adult hen stages. For each age group, we measured 300 to 400 AJRs in the sensory epithelium and 300 to 400 AJRs in the nonsensory epithelium. The mean AJR width in the sensory epithelium was $0.55 \pm 0.04$ $\mu \mathrm{m}$ for the five age groups, while in the nonsensory epithelium it was $0.49 \pm 0.02 \mu \mathrm{m}$. Most significantly, the dimensions of the AJRs in those epithelia do not change substantially as chickens develop and grow (Table 2, Fig. 6,7). TEM images of longitudinal and transverse sections confirmed the absence of appreciable circumferential band growth (Fig. 8A-F) and allowed us to measure the vertical dimensions of the AJRs, which averaged $0.4 \pm 0.09 \mu \mathrm{m}$ at 
$\mathrm{P} 0,0.4 \pm 0.08 \mu \mathrm{m}$ at $\mathrm{P} 9$, and $0.41 \pm 0.1 \mu \mathrm{m}$ at $\mathrm{P} 365$ ( $\mathrm{n} \geq 30$ cells), with a mean of $0.4 \pm 0.01$ $\mu \mathrm{m}$ for the three ages. The widths of the AJRs averaged $0.47 \pm 0.13 \mu \mathrm{m}$ at P0 and $0.53 \pm$ 0.12 at $\mathrm{P} 365(\mathrm{n} \geq 15 \mathrm{AJRs})$, with a mean of $0.5 \pm 0.04 \mu \mathrm{m}$ for the two ages. These data indicate that as chickens mature and grow from the hatchling stage to adulthood, the AJRs in their supporting cells remain considerably thinner than those in the utricles of embryonic day 18 mice.

\section{Utricular epithelia cultured from chickens spread independently of age}

The capacity for utricular supporting cells to change from their normal tall, columnar shapes to spread shapes diminishes sharply during the first weeks after rats and mice are born, as the circumferential F-actin bands in those cells greatly increase in thickness; and both those changes coincide with a sharp and progressive decline in their capacity for cell proliferation (Gu et al., 2007; Davies et. al, 2007; Meyers and Corwin, 2007). Since the circumferential F-actin bands in the supporting cells of chickens remain thin even in adulthood, we decided to test the hypothesis that mature avian supporting cells would retain the capacity for changing from columnar to spread shapes. For this, we isolated sheets of utricular sensory epithelium from chickens that ranged in age from P0 to P180 and cultured those epithelia on fibronectin-coated, glass-bottom dishes for $72 \mathrm{hr}$, while monitoring their spreading. In contrast to similarly explanted and cultured sheets of utricular sensory epithelium from mice, those from chickens spread at similar rates at all ages (Fig. 9). By the end of the $72 \mathrm{hr}$ culture period, the sensory epithelium sheets from the P0 chicks spread to occupy an area that was $\sim 11$-fold greater than the area those same sheets occupied $1 \mathrm{hr}$ after the culture was started, while those from P60 chickens spread $\sim 9$-fold and those from P180 hens spread $\sim 10$-fold (Fig. 10A).

\section{Spreading does not depend on proliferation in the first $\mathbf{7 2}$ hours of culture}

To test whether the spreading of those epithelia depended on cell production, we blocked proliferation by culturing other utricular epithelia from $\mathrm{P} 0$ and $\mathrm{P} 180$ chickens for $72 \mathrm{hr}$ in medium that contained the DNA polymerase inhibitor, aphidicolin, at $25 \mu \mathrm{M}$. The proliferation block was verified by culturing utricular epithelia with $3 \mu \mathrm{g} / \mathrm{ml} \mathrm{BrdU}$ and 25 $\mu \mathrm{M}$ aphidicolin for $72 \mathrm{hrs}$, which showed a $>99 \%$ reduction in the level of BrdU-positive nuclei from the level in parallel cultures in $3 \mu \mathrm{g} / \mathrm{ml}$ BrdU alone (data not shown). By $72 \mathrm{hr}$, the area occupied by the aphidicolin-treated sheet cultures from the P0 chicks increased $\sim 10$-fold, while those in control medium increased $\sim 11$-fold (Fig. 10B). Similarly, aphidicolin-treated sheet cultures from P180 chickens spread $\sim 9.4$-fold at $72 \mathrm{hr}$, while P180 control sheets spread $\sim 10$-fold (Fig. 10B). The results indicate the majority of the spreading of these sheets that occurs in the first $72 \mathrm{hrs}$ is the result of supporting cells changing shape, and not the result of cell addition.

\section{S-phase entry rates are high in utricular epithelia from young and old chickens}

To test whether the epithelia from chickens would show similar age-related declines in cell proliferation to those observed in rats and mice, we cultured utricular sheets of sensory epithelium from P0, P6, P12, P24, P60, P180, and P420 chickens and added BrdU to the medium $2 \mathrm{hr}$ before the end of the $72 \mathrm{hr}$ culture period. The results demonstrate that utricular sensory epithelia cultured from chickens from hatching to 420 days of age all retain the capacity for high rates of cell proliferation (Fig. 10).

\section{Thickening of the circumferential bands in human utricles}

We used fluorescently-conjugated phalloidin and confocal microscopy to investigate circumferential F-actin bands in supporting cells within the vestibular organs of cadavers from two 22-week-old human fetuses, which were aborted to save the life of the mother, and 
three cadavers of 60-to-65-year-old males, who died from natural causes. In these human samples, we selected and examined regions in the utricular sensory epithelia that did not show evidence of extensive hair cell loss (Fig. 11A-C). We used the same measurement methods employed for specimens from mice and chickens in determining that the widths of $\sim 100$ AJRs per utricle in the two 22-week-old fetal human utricles averaged $0.93 \pm 0.48 \mu \mathrm{m}$, while the widths from the three 60-to-65-year-old males averaged $3.52 \pm 0.2 \mu \mathrm{m}$, an increase of $\sim 278 \%$ from the fetal width. These preliminary results suggest that the circumferential Factin bands in human vestibular supporting cells increase with age in a manner similar to their counterparts in mice.

\section{DISCUSSION}

For years, neuroscientists have sought to identify differences in the ears of mammals that might help to account for the absence of the rapid and innate regeneration that leads to hearing and balance recovery in non-mammals. Here we have described a marked difference in the postnatal reinforcement of the bands of F-actin that bracket the apical junctions between vestibular supporting cells in mammals and birds. Between E18 and P52, the circumferential F-actin bands in mice become 13-fold thicker, with the steepest accumulation of F-actin occurring coincident with early postnatal declines in the capacity for supporting cells to spread and proliferate near sites of injury. Preliminary observations show similar growth in humans. In chickens, the equivalent $\mathrm{F}$-actin bands remain thin throughout life, and supporting cells respond to injury to the epithelium with high levels of spreading and proliferation that do not decline with age. Continuing investigations of these fundamental differences in cellular structure and response may help identify the characteristics of mammalian ears that limit the cellular responses to injury that normally precede hair cell regeneration in non-mammals.

\section{An unusual pattern of circumferential band growth}

We are not aware of any cells outside the inner ear that develop circumferential F-actin bands approaching the relative size of those observed in the utricular supporting cells of adult mice and humans. The measured width of F-actin bands averages $0.5 \pm 0.1 \mu \mathrm{m}$ in cells of the retinal pigmented epithelium in sexually mature rats (Gordon and Essner, 1987), which is comparable to the width of the AJRs in the P0 mice examined in this study. Published measurements of F-actin bands in other cell types are limited. However, TEM images of the circumferential F-actin bands in ependymal cells of adult rodents (Sturrock, 1981; Bruni and Reddy, 1986), cells in adult human olfactory epithelium (Moran et al., 1982; Steinke et al., 2008), cells in adult human epidermis (Haftek et al., 1996; Ishiko et al., 2003), and cells in intestinal epithelium in adult rodents and humans (Farquhar and Palade, 1963; Drenckhahn and Dermietzel, 1988) are qualitatively similar in size and structure to those observed in our investigation of supporting cells in chickens, young mice, and fetal humans. Although the dimensions of the F-actin bands imaged in the aforementioned studies were not provided, scale bars were, so we determined that the circumferential bands in those images represented the equivalent of AJRs with widths that ranged from 0.6 to $1 \mu \mathrm{m}$, which is in the range of supporting cell AJR widths in embryonic mice and chickens at all ages.

We have not determined how F-actin is added to the growing circumferential bands as mice and humans mature. It is possible that the bands grow by adding new filaments within or through apposition to the edges of the bundles of anti-parallel F-actin filaments that have been characterized in ultrastructural investigations of the circumferential bands in the supporting cells of young birds and mammals (Hirokawa and Tilney, 1982; Slepecky and Chamberlain, 1983). Alternatively, these bands may start out with all or most of the filaments organized in bundles that parallel the cell membrane in young mammals and later transition into inwardly growing branched meshworks of filaments or anastomosing 
collections of bundles as mammalian supporting cells mature. Since bundles and branched meshworks are likely to have different mechanical and physiological properties, it will be important to explore those possibilities.

\section{Implications of circumferential band reinforcement}

An apparent bottleneck develops as the F-actin bands in maturing mammals grow to occupy nearly $90 \%$ of the internal area at the level of the supporting cell's adherens junction (Fig. 12). Such growth is likely to have physiological costs that could be offset by benefits stemming from this unique form of cytoskeletal reinforcement. Tilney and colleagues suggested that sliding of the antiparallel actin filaments that comprise the circumferential bands in supporting cells could lead to changes in the anchoring of hair cells (Hirokawa and Tilney, 1982;Drenckhahn et al., 1991). The 13-fold thickness increase that develops as mammals mature also could contribute to more rigid anchoring of the hair cell's mechanotransduction apparatus. That, in turn, may contribute to improvements in sensitivity and frequency response. In fact, during the same early postnatal period when we measured the steepest circumferential band growth in mice, vestibular function is reported to improve significantly (Schonfelder and Schwartze, 1970; Hard and Larson, 1975;Parrad and Cottereau, 1977).

Qualitative studies in rodents and bats have shown that F-actin accumulates in the organ of Corti's reticular lamina between birth and the onset of hearing, which normally begins in rodents during the second week after birth (Mikaelian and Ruben, 1965; Ehret, 1976; Kraus and Aulbach-Kraus, 1981; Ehret, 1985; Kuhn and Vater, 1996). That reticular lamina is comprised in large part of a robust network formed by the circumferential F-actin bands that bracket the junctions between the heads of three types of specialized supporting cells: Deiters cells, inner pillar cells, and outer pillar cells (Slepecky and Chamberlain, 1983, 1986; Raphael et al., 1993, 1994; Kuhn and Vater, 1996; Leonova and Raphael, 1997). In some studies, the network of circumferential Factin bands in the utricule's supporting cells has also been referred to as a reticular lamina (Bagger-Sjoback and Anniko, 1984; Takumida et al., 1994).

Developmental differences in the growth of the F-actin bands are not the only structural attributes of cell junctions that differ between the ears of birds and mammals. In the vestibular epithelia, E- and N-cadherin expression patterns differ as well (Raphael et al., 1988; Hackett et al., 2002; Kim et al., 2002, 2005; Warchol, 2002). E-cadherin is expressed only weakly in the sensory epithelium of the chicken utricle (Warchol, 2007). In contrast, Western Blots have provided quantitative evidence that the levels of E-cadherin increase significantly and the levels of beta-catenin decrease significantly in the utricular sensory epithelia from mice during the first postnatal week as proliferative responses decline most steeply (Lu and Corwin, 2008). In the mature mammalian organ of Corti, immunostaining for E-cadherin has revealed intense labeling at apical supporting cell junctions (Whitlon, 1993; Whitlon et al., 1999; Simonneau et al., 2003), while E-cadherin immunostaining is weak in supporting cells of the chicken's basilar papilla auditory epithelium (Richardson et al., 1987; Raphael et al., 1988).

In addition to the actin cytoskeleton, developmental changes and species differences in keratin intermediate filaments and microtubules also should be investigated for their potential to influence regenerative responses in the ears of mammals and non-mammals. In the Bullfrog saccule, keratin expression ceases in hair cells after they have differentiated but is maintained in supporting cells (Cyr et al., 2000). Keratin intermediate filaments and microtubules also are important elements of supporting cell cytoskeletons in the organ of Corti and the utricle in mammals (Usami et al., 1993; Slepecky et al., 1995; Takumida et al., 
1994; Tannenbaum and Slepecky, 1997; Mogensen et al., 1998; Tucker et al., 1999; Saha and Slepecky, 2000).

\section{Estimating the mechanical effects of the growth of the F-actin bands}

To a first approximation, the stiffness of the F-actin bands we have measured can be estimated by modeling the bands as solid beams with an elliptical cross-section. For such a beam, the bending rigidity is $\kappa_{B}=E I$, where $E$ is Young's modulus and $I$ is the second moment of inertia. If the material that comprises the beam has a constant Young's Modulus, then the bending rigidity in the plane of the major axis through the elliptical cross-section of the band would increase in proportion to $I=\frac{\pi}{4} a b^{3}$, where $a$ is half the vertical dimension and $b$ is half the horizontal dimension of the band's cross-section. Using values for $a$ and $b$ from our ultrastructural measurements, the model predicts that the bands in P52 mouse utricles would have $\sim 145$ times the vertical bending rigidity of the bands in E18 utricles. In the minor (horizontal) axis, bending rigidity would increase in proportion to $I=\frac{\pi}{4} a^{3} b$ and would be 292 times greater in a P52 mouse than in an E18 mouse.

This model is based on classical continuum mechanics equations and therefore does not incorporate microstructural influences relating to meshwork density or filament alignment. Interactions between F-actin and motor proteins, such as myosin II or myosin 1c, which have been localized to the apical portion of supporting cells (Sans et al., 1989; Drenckhahn et al., 1991; Gillespie et al., 1993; Hasson et al., 1997; Cyr et al., 2002) could contribute to increases or decreases in Young's modulus. Although the actin bundling espins are not found in supporting cells (Zheng et al., 2000), interactions with actin binding proteins such as tropomyosin and alpha-actinin, which have been localized to the circumferential F-actin band in supporting cells (Drenckhahn et al., 1991), could result in deviations from the simple model used here for the purpose of estimation. A more complex model would be needed to estimate such microstructural effects and the effects of the geometric loading of the bands. Still, it appears safe to conclude that the large observed increases in F-actin band thickness are likely to result in significant increases in bending rigidity as mammalian ears mature.

The difference in the bending rigidity of the F-actin bands between supporting cells in the ears of mature birds and mammals is likely to be even greater since the bands in 1-year-old chickens are significantly thinner than those in E18 mice. While actual measurements of supporting cell stiffness remain to be made, for regeneration, the pertinent question is whether the growth of the F-actin bands affects proliferation or changes in cellular phenotype.

\section{The role of cellular shape change in regulating proliferation}

Experiments with cultured cells have shown that spread cellular shapes can be necessary for entry into S-phase, even in the presence of excess mitogens (Folkman and Moscona, 1978; Kulesh and Greene, 1986; Watt et al., 1988; Chen et al., 1997; Liu et al., 2006). When the ear's hair cells are damaged in vivo, the apical surfaces of supporting cells expand (Forge, 1985). In avian hearing organs, supporting cell expansion precedes S-phase entry and the replacement of lost hair cells (Cotanche, 1987; Corwin and Cotanche, 1988; Cotanche and Dopyera, 1990; Marsh et al., 1990; Stone and Cotanche, 1994). When hair cell epithelia are cultured, the supporting cells that are near the cut edges of the epithelium are the first to change from their normal tall and narrow columnar shapes ( $\sim 30 \mu \mathrm{m}$ height, $<5 \mu \mathrm{m}$ wide) to thin and widely spread shapes ( $\leq 2 \mu \mathrm{m}$ height, 30-65 $\mu \mathrm{m}$ wide) (Gu et al., 1996, 1997, 2007; Witte et al., 2001; Warchol, 2002; Meyers and Corwin, 2007). S-phase entry is positively correlated with supporting cell spreading near such cut edges and inversely correlated to cell 
density in cultured vestibular epithelia from chicks (Witte et al., 2001; Warchol, 2002), which is consistent with results reported here (Fig. 10). Spreading and proliferation are also high in utricular epithelia explanted from adult chickens (Fig. 10), E18 mice (Davies et al., 2007), and newborn rats (Gu et al., 2007); but $72 \mathrm{hr}$ explants from 2-week-old rodents show considerably less spreading and proliferation (Davies et al., 2007; Gu et al., 2007).

Results from experiments in which cell turnover was suppressed appear to be consistent with the proposal that cellular spreading regulates proliferation in these sensory epithelia, potentially even in small-scale wounds. When whole utricles from chickens were incubated with caspase inhibitors, supporting cell proliferation decreased in a dose-dependent manner, which was consistent with an expected reduction in ongoing hair cell apoptosis and a concomitant decrease in the creation of vacancies in the epithelium into which supporting cells could spread (Matsui et al., 2002). However, when caspase inhibitors were added to cultures that had been made by isolating and explanting just the hair cell epithelium itself, supporting cells were observed to proliferate at similar levels in both caspase-treated and control cultures (Matsui et al., 2002). Other research has shown that hair cell death is not required for the supporting cells in such isolated epithelium cultures to exhibit substantial levels of cellular shape change as they spread outward from the cut edges of explants (Davies et al., 2007).

When excision wounds heal in utricles from young mice, significant numbers of supporting cells that were originally somewhat distant from the wound edge are recruited into wound closure, and the supporting cells that cover the wounds spread to individual areas of 250 $\mu \mathrm{m}^{2}$ or less. In contrast, when such wounds heal in 2-week-old utricles, even the cells that are just two or three rows back from the leading edge show little spreading, so the wounds are covered by small numbers of leading edge supporting cells that can spread to individual areas $>1200 \mu \mathrm{m}^{2}$. Interestingly, those experiments revealed a quantitative relationship between the spread areas individual supporting cells come to occupy and their probability for proliferation, with cells that spread to $>400 \mu \mathrm{m}^{2}$ having an $85 \%$ probability of entering S-phase during the 7 days after the wounds were created (Meyers and Corwin, 2007).

\section{F-actin band thickness appears to influence cell spreading and proliferation}

The growth of F-actin bands may provide an explanation for the observations described above since the thicker bands in older mammalian utricles would be likely to contribute to greater intracellular stiffness, which could allow cells that are just slightly distant from the wound edge to resist the traction forces that lead to wound closure. The growth of the Factin bands also may explain the differences observed in explant spreading between chickens and mice. To evaluate such an explanation, we used published values for the spreading of utricular explants that occurs in cultures from mice ranging in age from E18 to P21 (Davies et al., 2007) and determined that the Pearson correlation coefficient for spreading and F-actin band growth is -0.989 . Then we used published values for proliferation in utricular explants from mice ranging in age from E18 to P28 ( $\mathrm{Lu}$ and Corwin, 2008) and determined that the Pearson correlation coefficient for proliferation and F-actin band growth is -0.975 . While such inverse correlations cannot establish causation, they are fully consistent with the notion that the thickness increase that occurs as the circumferential bands in mammalian ears mature may impede cellular shape change and the production of new cells at sites of injury. On the other hand, the persistence of thin bands in chickens may contribute to the lifelong capacity for large numbers of supporting cells to change shape and divide in response to injury. Whether reinforced F-actin bands will correlate with limits to cell shape change and cell division that are evoked by smaller wounds, such as those created through the loss of individual hair cells, remains to be determined. 
Taken together, the current evidence is consistent with the possibility that proliferation in vestibular epithelia is regulated, in part, by increased cellular stiffness or another as yet unidentified attribute of cellular shape change itself, which acts upstream of proliferation controls and downstream of the activated Rac and Rho that can drive different forms of motility. An alternative hypothesis is that loss of contact inhibition with neighboring supporting cells may trigger signals at cell junctions to induce S-phase entry; however, the current evidence points to shape change as an important influence in the control of cell proliferation, at least in murine sensory epithelia, since the probability of proliferation is low for cells which have lost contact with their neighbors but have retained their normal columnar, unspread shape (Meyers and Corwin, 2007).

While much remains for investigation, the findings reported here may help to explain the clinical permanence of hair cell deficits in humans and other mammals. The reinforcement of the F-actin bands in humans and mice could limit the types of cellular shape changes and cell production that occur innately in response to injury and during hair cell regeneration in birds and other nonmammalian vertebrates. The robust F-actin bands that develop during the early postnatal maturation of the mammalian ear may, therefore, provide potential pharmaceutical targets for efforts to stimulate therapeutic regeneration.

\section{Supplementary Material}

Refer to Web version on PubMed Central for supplementary material.

\section{Acknowledgments}

Supported by funds from NIH R01-DC00200 to J.T.C.

\section{REFERENCES}

Bagger-Sjoback D, Anniko M. Development of intercellular junctions in the vestibular end-organ. A freeze-fracture study in the mouse. Ann Otol Rhinol Laryngol. 1984; 93(1 Pt 1):89-95. [PubMed: 6608311]

Bruni JE, Reddy K. Ependyma of the central canal of the rat spinal cord: a light and transmission electron microscopic study. J Anat. 1987; 152:55-70. [PubMed: 3654376]

Chen CS, Mrksich M, Huang S, Whitesides GM, Ingber DE. Geometric control of cell life and death. Science. 1997; 276(5317):1425-1428. [PubMed: 9162012]

Corwin JT, Cotanche DA. Regeneration of sensory hair cells after acoustic trauma. Science. 1988; 240(4860):1772-1774. [PubMed: 3381100]

Cotanche DA. Regeneration of hair cell stereociliary bundles in the chick cochlea following severe acoustic trauma. Hear Res. 1987; 30(2-3):181-195. [PubMed: 3680064]

Cotanche DA, Dopyera CE. Hair cell and supporting cell response to acoustic trauma in the chick cochlea. Hear Res. 1990; 46(1-2):29-40. [PubMed: 2380125]

Cyr JL, Bell AM, Hudspeth AJ. Identification with a recombinant antibody of an inner-ear cytokeratin, a marker for hair-cell differentiation. Proc Natl Acad Sci U S A. 2000; 97(9):4908-4913. [PubMed: 10758152]

Cyr JL, Dumont RA, Gillespie PG. Myosin-1c interacts with hair-cell receptors through its calmodulin-binding IQ domains. J Neurosci. 2002; 22(7):2487-2495. [PubMed: 11923413]

Davies D, Magnus C, Corwin JT. Developmental changes in cell-extracellular matrix interactions limit proliferation in the mammalian inner ear. Eur J Neurosci. 2007; 25(4):985-998. [PubMed: 17331195]

Drenckhahn D, Dermietzel R. Organization of the actin filament cytoskeleton in the intestinal brush border: a quantitative and qualitative immunoelectron microscope study. J Cell Biol. 1988; 107(3): 1037-1048. [PubMed: 3417773] 
Drenckhahn D, Engel K, Hofer D, Merte C, Tilney L, Tilney M. Three different actin filament assemblies occur in every hair cell: each contains a specific actin crosslinking protein. J Cell Biol. 1991; 112(4):641-651. [PubMed: 1993735]

Dunnington EA, Siegel PB. Age and body weight at sexual maturity in female white Leghorn chickens. Poult Sci. 1984; 63(4):828-830. [PubMed: 6728783]

Ehret G. Development of absolute auditory thresholds in the house mouse (Mus musculus). J Am Audiol Soc. 1976; 1(5):179-184. [PubMed: 956003]

Ehret G. Behavioural studies on auditory development in mammals in relation to higher nervous system functioning. Acta Otolaryngol. 1985; 421(Suppl):31-40.

Farquhar MG, Palade GE. Junctional complexes in various epithelia. J Cell Biol. 1963; 17:375-412. [PubMed: 13944428]

Folkman J, Moscona A. Role of cell shape in growth control. Nature. 1978; 273(5661):345-349. [PubMed: 661946]

Forge A. Outer hair cell loss and supporting cell expansion following chronic gentamicin treatment. Hear Res. 1985; 19(2):171-182. [PubMed: 4055536]

Gillespie PG, Wagner MC, Hudspeth AJ. Identification of a $120 \mathrm{kd}$ hair-bundle myosin located near stereociliary tips. Neuron. 1993; 11(4):581-594. [PubMed: 8398149]

Gordon SR, Essner E. Investigations on circumferential microfilament bundles in rat retinal pigment epithelium. Eur J Cell Biol. 1987; 44(1):97-104. [PubMed: 3305027]

Gratzner HG. Monoclonal antibody to 5-bromo- and 5-iododeoxyuridine: A new reagent for detection of DNA replication. Science. 1982; 218(4571):474-475. [PubMed: 7123245]

Gu R, Marchionni M, Corwin JT. Glial growth factor enhances supporting cell proliferation in rodent vestibular epithelia cultured in isolation. Soc Neurosci Abstr. 1996; 21

Gu R, Marchionni M, Corwin JT. Age-related decreases in proliferation within isolated mammalian vestibular epithelia cultured in control and glial growth factor 2 medium. Assoc Res Otolaryngol Abstr. 1997; 20

Gu R, Montcouquiol M, Marchionni M, Corwin JT. Proliferative responses to growth factors decline rapidly during postnatal maturation of mammalian hair cell epithelia. Eur J Neurosci. 2007; 25(5): 1363-1372. [PubMed: 17425563]

Hackett L, Davies D, Helyer R, Kennedy H, Kros C, Lawlor P, Rivolta MN, Holley M. E-cadherin and the differentiation of mammalian vestibular hair cells. Exp Cell Res. 2002; 278(1):19-30. [PubMed: 12126954]

Haftek M, Hansen MU, Kaiser HW, Kreysel HW, Schmitt D. Interkeratinocyte adherens junctions: immunocytochemical visualization of cell-cell junctional structures, distinct from desmosomes, in human epidermis. J Invest Dermatol. 1996; 106(3):498-504. [PubMed: 8648183]

Hard E, Larsson K. Development of air righting in rats. Brain Behav Evol. 1975; 11(1):53-59. [PubMed: 1174931]

Hasson T, Gillespie PG, Garcia JA, MacDonald RB, Zhao Y, Yee AG, Mooseker MS, Corey DP. Unconventional myosins in inner-ear sensory epithelia. J Cell Biol. 1997; 137(6):1287-1307. [PubMed: 9182663]

Hirokawa N, Tilney LG. Interactions between actin filaments and between actin filaments and membranes in quick-frozen and deeply etched hair cells of the chick ear. J Cell Biol. 1982; 95(1): 249-261. [PubMed: 6890555]

Ishiko A, Matsunaga Y, Masunaga T, Aiso S, Nishikawa T, Shimizu H. Immunomolecular mapping of adherens junction and desmosomal components in normal human epidermis. Exp Dermatol. 2003; 12(6):747-754. [PubMed: 14714553]

Jorgensen JM, Mathiesen C. The avian inner ear. Continuous production of hair cells in vestibular sensory organs, but not in the auditory papilla. Naturwissenschaften. 1988; 75(6):319-320. [PubMed: 3205314]

Kelley MW, Xu XM, Wagner MA, Warchol ME, Corwin JT. The developing organ of Corti contains retinoic acid and forms supernumerary hair cells in response to exogenous retinoic acid in culture. Development. 1993; 119(4):1041-1053. [PubMed: 8306874] 
Kim TS, Nakagawa T, Endo T, Iguchi F, Murai N, Naito Y, Ito J. Alteration of E-cadherin and betacatenin in mouse vestibular epithelia during induction of apoptosis. Neurosci Lett. 2002; 329(2): 173-176. [PubMed: 12165405]

Kim TS, Nakagawa T, Kitajiri S, Endo T, Takebayashi S, Iguchi F, Kita T, Tamura T, Ito J. Disruption and restoration of cell-cell junctions in mouse vestibular epithelia following aminoglycoside treatment. Hear Res. 2005; 205(1-2):201-209. [PubMed: 15953529]

Kraus HJ, Aulbach-Kraus K. Morphological changes in the cochlea of the mouse after the onset of hearing. Hear Res. 1981; 4(1):89-102. [PubMed: 7204263]

Kuhn B, Vater M. The early postnatal development of F-actin patterns in the organ of Corti of the gerbil (Meriones unguiculatus) and the horseshoe bat (Rhinolophus rouxi). Hear Res. 1996; 99(1-2):47-70. [PubMed: 8970813]

Kulesh DA, Greene JJ. Shape-dependent regulation of proliferation in normal and malignant human cells and its alteration by interferon. Cancer Res. 1986; 46(6):2793-2797. [PubMed: 2421883]

Lambert PR, Gu R, Corwin JT. Analysis of small hair bundles in the utricles of mature guinea pigs. Am J Otol. 1997; 18(5):637-643. [PubMed: 9303162]

Leonova EV, Raphael Y. Organization of cell junctions and cytoskeleton in the reticular lamina in normal and ototoxically damaged organ of Corti. Hear Res. 1997; 113(1-2):14-28. [PubMed: 9387983]

Liu WF, Nelson CM, Pirone DM, Chen CS. E-cadherin engagement stimulates proliferation via Rac1. J Cell Biol. 2006; 173(3):431-441. [PubMed: 16682529]

Lu Z, Corwin JT. The influence of glycogen synthase kinase 3 in limiting cell addition in the mammalian ear. Dev Neurobiol. 2008; 68(8):1059-1075. [PubMed: 18470861]

Marsh RR, Xu LR, Moy JP, Saunders JC. Recovery of the basilar papilla following intense sound exposure in the chick. Hear Res. 1990; 46(3):229-237. [PubMed: 2394635]

Matsui JI, Ogilvie JM, Warchol ME. Inhibition of caspases prevents ototoxic and ongoing hair cell death. J Neurosci. 2002; 22(4):1218-1227. [PubMed: 11850449]

Matsunami H, Takeichi M. Fetal brain subdivisions defined by R- and E-cadherin expressions: evidence for the role of cadherin activity in region-specific, cell-cell adhesion. Dev Biol. 1995; 172(2):466-478. [PubMed: 8612964]

Meyers JR, Corwin JT. Shape change controls supporting cell proliferation in lesioned mammalian balance epithelium. J Neurosci. 2007; 27(16):4313-4325. [PubMed: 17442815]

Meyers, JR.; Corwin, JT. Morphological Correlates of Regeneration and Repair. In: Salvi, RJ.; Fay, RR.; Popper, AN., editors. Hair Cell Regeneration, Repair, and Protection. Springer; New York City: 2008. p. 39-75.

Mikaelian DO, Ruben RJ. Development of hearing in the normal CBA-J mouse. Acta OtoLaryngologica. 1965; 59(2-6):451-461.

Mogensen MM, Henderson CG, Mackie JB, Lane EB, Garrod DR, Tucker JB. Keratin filament deployment and cytoskeletal networking in a sensory epithelium that vibrates during hearing. Cell Motil Cytoskeleton. 1998; 41(2):138-153. [PubMed: 9786089]

Montcouquiol M, Corwin JT. Brief treatments with forskolin enhance s-phase entry in balance epithelia from the ears of rats. J Neurosci. 2001a; 21(3):974-982. [PubMed: 11157083]

Montcouquiol M, Corwin JT. Intracellular signals that control cell proliferation in mammalian balance epithelia: key roles for phosphatidylinositol-3 kinase, mammalian target of rapamycin, and S6 kinases in preference to calcium, protein kinase $\mathrm{C}$, and mitogen-activated protein kinase. $\mathrm{J}$ Neurosci. 2001b; 21(2):570-580. [PubMed: 11160436]

Moran DT, Rowley JC 3rd, Jafek BW. Electron microscopy of human olfactory epithelium reveals a new cell type: the microvillar cell. Brain Res. 1982; 253(1-2):39-46. [PubMed: 7150975]

Parrad J, Cottereau P. [Appearance of rotatory reactions in the newborn rat (author's transl)]. Physiol Behav. 1977; 18(6):1017-1020. [PubMed: 303779]

Raphael Y, Athey BD, Wang Y, Hawkins JE Jr. Structure of the reticular lamina and repair after noise injury. Rev Laryngol Otol Rhinol (Bord). 1993; 114(3):171-175. [PubMed: 8191059]

Raphael Y, Athey BD, Wang Y, Lee MK, Altschuler RA. F-actin, tubulin and spectrin in the organ of Corti: comparative distribution in different cell types and mammalian species. Hear Res. 1994; 76(1-2):173-187. [PubMed: 7928710] 
Raphael Y, Volk T, Crossin KL, Edelman GM, Geiger B. The modulation of cell adhesion molecule expression and intercellular junction formation in the developing avian inner ear. Dev Biol. 1988; 128(1):222-235. [PubMed: 3289987]

Richardson GP, Crossin KL, Chuong CM, Edelman GM. Expression of cell adhesion molecules during embryonic induction. III. Development of the otic placode. Dev Biol. 1987; 119(1):217-230. [PubMed: 3792629]

Ryals BM, Rubel EW. Hair cell regeneration after acoustic trauma in adult Coturnix quail. Science. 1988; 240(4860):1774-1776. [PubMed: 3381101]

Saha S, Slepecky NB. Age-related changes in microtubules in the guinea pig organ of Corti. Tubulin isoform shifts with increasing age suggest changes in micromechanical properties of the sensory epithelium. Cell Tissue Res. 2000; 300(1):29-46. [PubMed: 10805073]

Sans A, Atger P, Cavadore C, Cavadore JC. Immunocytochemical localization of myosin, tropomyosin and actin in vestibular hair cells of human fetuses and cats. Hear Res. 1989; 40(1-2):117-125. [PubMed: 2768077]

Schonfelder J, Schwartze P. [Development of the falling flip-over reflex in the ontogenesis of rabbits]. Acta Biol Med Ger. 1970; 25(1):109-114. [PubMed: 5530838]

Simonneau L, Gallego M, Pujol R. Comparative expression patterns of T-, N-, E-cadherins, betacatenin, and polysialic acid neural cell adhesion molecule in rat cochlea during development: implications for the nature of Kolliker's organ. J Comp Neurol. 2003; 459(2):113-126. [PubMed: 12640664]

Slepecky N, Chamberlain SC. Distribution and polarity of actin in inner ear supporting cells. Hear Res. 1983; 10(3):359-370. [PubMed: 6683721]

Slepecky N, Chamberlain SC. Correlative immuno-electron-microscopic and immunofluorescent localization of actin in sensory and supporting cells of the inner ear by use of a low-temperature embedding resin. Cell Tissue Res. 1986; 245(2):229-235. [PubMed: 3527421]

Slepecky NB, Henderson CG, Saha S. Post-translational modifications of tubulin suggest that dynamic microtubules are present in sensory cells and stable microtubules are present in supporting cells of the mammalian cochlea. Hear Res. 1995; 91(1-2):136-147. [PubMed: 8647715]

Steinke A, Meier-Stiegen S, Drenckhahn D, Asan E. Molecular composition of tight and adherens junctions in the rat olfactory epithelium and fila. Histochem Cell Biol. 2008

Stone JS, Cotanche DA. Identification of the timing of S phase and the patterns of cell proliferation during hair cell regeneration in the chick cochlea. J Comp Neurol. 1994; 341(1):50-67. [PubMed: 8006223]

Sturrock RR. An electron microscopic study of the development of the ependyma of the central canal of the mouse spinal cord. J Anat. 1981; 132(Pt 1):119-136. [PubMed: 7275786]

Svitkina TM, Borisy GG. Correlative light and electron microscopy of the cytoskeleton of cultured cells. Methods Enzymol. 1998; 298:570-592. [PubMed: 9751908]

Takumida M, Anniko M. Cytoskeletal organization of the vestibular supporting cells. Saponin perfusion method for observing intracellular structures by scanning electron microscopy. Acta Otolaryngol. 1994; 114(2):150-155. [PubMed: 8203196]

Tannenbaum J, Slepecky NB. Localization of microtubules containing posttranslationally modified tubulin in cochlear epithelial cells during development. Cell Motil Cytoskeleton. 1997; 38(2):146162. [PubMed: 9331219]

Tucker JB, Mackie JB, Bussoli TJ, Steel KP. Cytoskeletal integration in a highly ordered sensory epithelium in the organ of Corti: reponse to loss of cell partners in the Bronx waltzer mouse. $\mathrm{J}$ Neurocytol. 1999; 28(12):1017-1034. [PubMed: 11054902]

Usami S, Hozawa J, Shinkawa H, Saito S, Matsubara A, Fujita S. Immunocytochemical localization of intermediate filaments in the guinea pig vestibular periphery with special reference to their alteration after ototoxic drug administration. Acta Otolaryngol. 1993; 506(Suppl):7-13.

Warchol ME. Cell density and N-cadherin interactions regulate cell proliferation in the sensory epithelia of the inner ear. J Neurosci. 2002; 22(7):2607-2616. [PubMed: 11923426]

Warchol ME. Characterization of supporting cell phenotype in the avian inner ear: implications for sensory regeneration. Hear Res. 2007; 227(1-2):11-18. [PubMed: 17081713] 
Warchol ME, Corwin JT. Regenerative proliferation in organ cultures of the avian cochlea: identification of the initial progenitors and determination of the latency of the proliferative response. J Neurosci. 1996; 16(17):5466-5477. [PubMed: 8757259]

Warchol ME, Lambert PR, Goldstein BJ, Forge A, Corwin JT. Regenerative proliferation in inner ear sensory epithelia from adult guinea pigs and humans. Science. 1993; 259(5101):1619-1622. [PubMed: 8456285]

Watt FM, Jordan PW, O'Neill CH. Cell shape controls terminal differentiation of human epidermal keratinocytes. Proc Natl Acad Sci U S A. 1988; 85(15):5576-5580. [PubMed: 2456572]

White PM, Doetzlhofer A, Lee YS, Groves AK, Segil N. Mammalian cochlear supporting cells can divide and trans-differentiate into hair cells. Nature. 2006; 441(7096):984-987. [PubMed: 16791196]

Whitlon DS. E-cadherin in the mature and developing organ of Corti of the mouse. J Neurocytol. 1993; 22(12):1030-1038. [PubMed: 8106878]

Whitlon DS, Zhang X, Pecelunas K, Greiner MA. A temporospatial map of adhesive molecules in the organ of Corti of the mouse cochlea. J Neurocytol. 1999; 28(10-11):955-968. [PubMed: 10900097]

Witte MC, Montcouquiol M, Corwin JT. Regeneration in avian hair cell epithelia: identification of intracellular signals required for S-phase entry. Eur J Neurosci. 2001; 14(5):829-838. [PubMed: 11576187]

Zheng JL, Helbig C, Gao WQ. Induction of cell proliferation by fibroblast and insulin-like growth factors in pure rat inner ear epithelial cell cultures. J Neurosci. 1997; 17(1):216-226. [PubMed: 8987750]

Zheng JL, Lewis AK, Gao WQ. Establishment of conditionally immortalized rat utricular epithelial cell lines using a retrovirus-mediated gene transfer technique. Hear Res. 1998; 117:13-23.1-2 [PubMed: 9557974]

Zheng L, Sekerkova G, Vranich K, Tilney LG, Mugnaini E, Bartles JR. The deaf jerker mouse has a mutation in the gene encoding the espin actin-bundling proteins of hair cell stereocilia and lacks espins. Cell. 2000; 102(3):377-385. [PubMed: 10975527] 

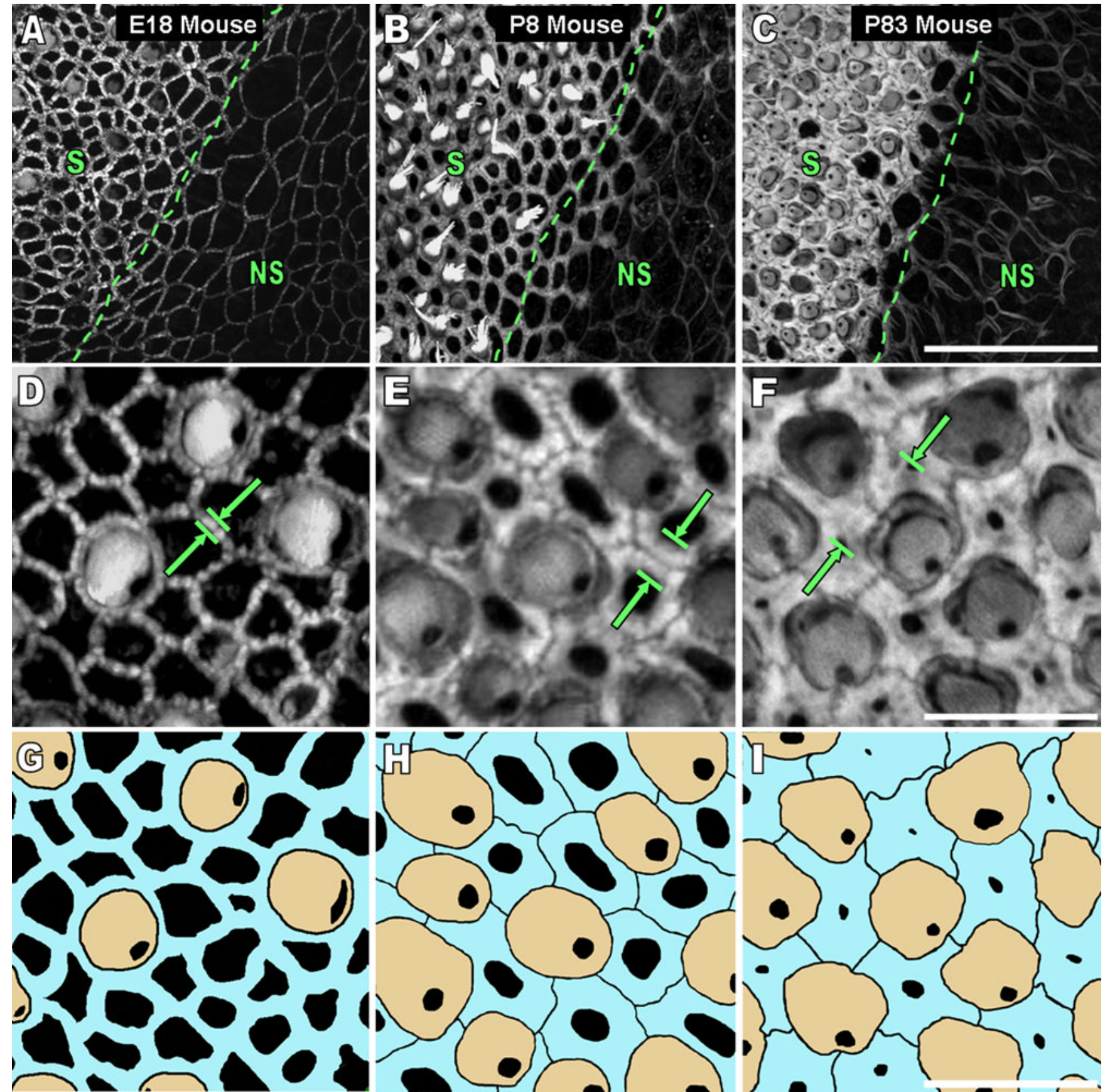

Figure 1.

The width of circumferential F-actin bands in utricular supporting cells of the sensory epithelium and cells of the nonsensory epithelium increases in mice as they develop and mature. A-C) The images are high resolution (63x 1.4NA objective, $0.3 \mu \mathrm{m}$ thick confocal sections) 2-D z-projections of a stack of images starting at least $5 \mu \mathrm{m}$ above and ending at least $5 \mu \mathrm{m}$ below where the bands were detectable from utricles of mice ages embryonic day 18 (E18), postnatal day 8 (P8), and P83. The transition from sensory epithelium (S) to nonsensory epithelium (NS) shows the difference in width of F-actin bands between these two regions as mice age. Circumferential F-actin bands extend further from the cell junctions towards the center of the cell in the $\mathrm{S}$ than in the NS as mice develop and mature. 
Scale bar for A-C in C, $30 \mu \mathrm{m}$. D-F) A high magnification image of the S in the frames in A shows that the width of F-actin bands (green arrows) in supporting cells of the $\mathrm{S}$ increases almost to the extent of covering the entire apical surface area of the supporting cells by P83. Scale bar for D-F in F, $10 \mu \mathrm{m}$. G-I) An overlay of the image in B shows the circumferential F-actin bands of supporting cells (blue) in relation to the actin-rich cuticular plates of hair cells (tan). A gap between the F-actin bands of adjacent supporting cells becomes resolvable as mice age, and as a result, the outlines of individual supporting cells are seen in the P8 and P83 mouse frames. Scale bar for G-I in I, $10 \mu \mathrm{m}$. 

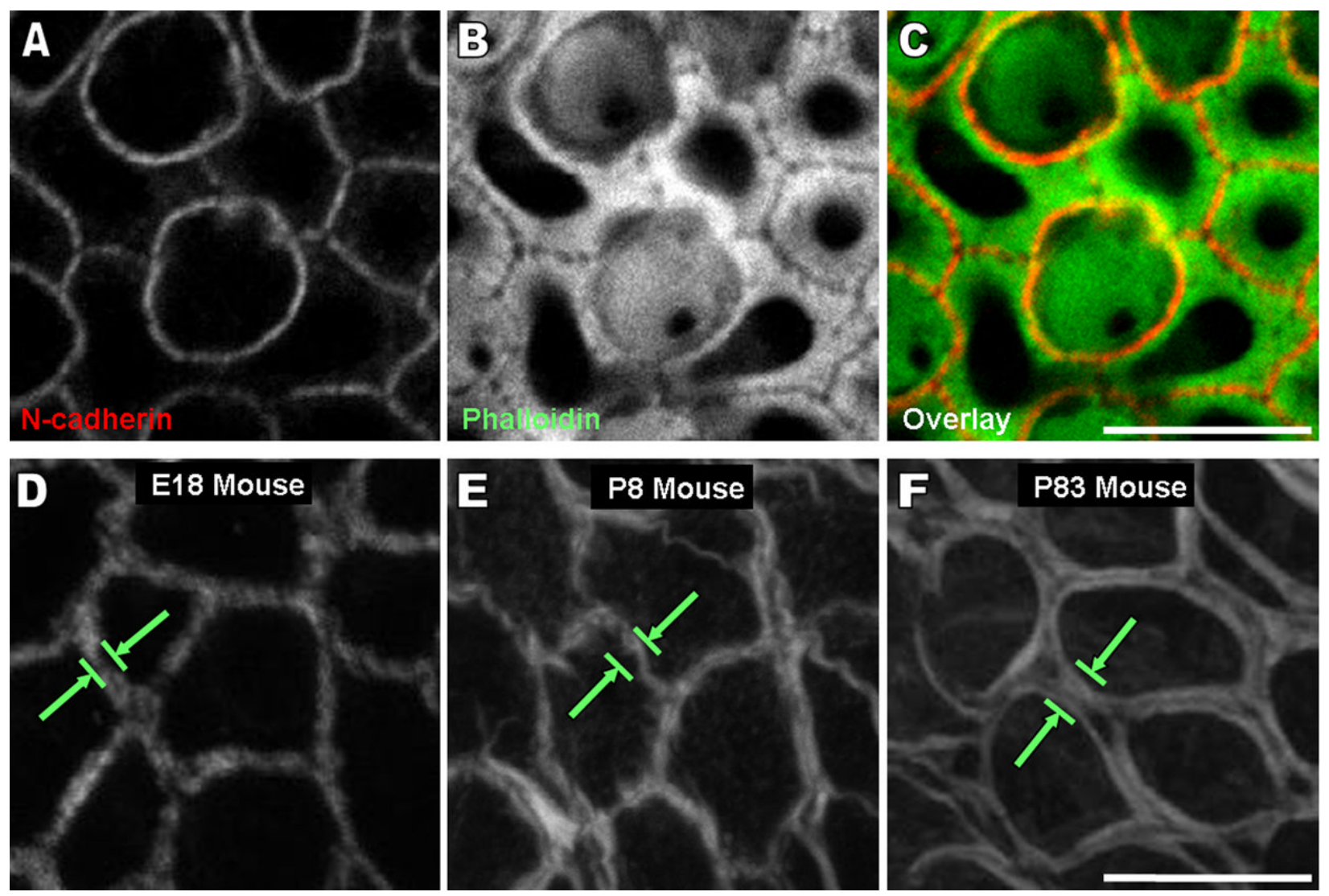

Figure 2.

A space between the circumferential F-actin bands of adjacent supporting cells which becomes resolvable as mice age is at the level of the adherens junctions. A-C) Images of Ncadherin immunohistochemistry (red), phalloidin staining (green), and their overlaid image show there is a visible gap between the F-actin bands at the intercellular adherens junction joining supporting cells in a postnatal day 8 mouse utricle. These frames are a single $0.3 \mu \mathrm{m}$ thick confocal slice at the $\mathrm{z}$-depth where the fluorescence intensity of $\mathrm{N}$-cadherin immunohistochemistry was at its highest. A large accumulation of F-actin was visible at this depth. Scale bar for A-C in C, $5 \mu \mathrm{m}$. D-F) High magnification images of cells from the nonsensory epithelium from Fig. 1A show the width of circumferential F-actin bands increases in cells of the nonsensory epithelium as mice age, but not to the extent that it does in supporting cells of the sensory epithelium. Scale bar for D-F in F, $10 \mu \mathrm{m}$. (A magentagreen version of this figure is provided in the supplementary material) 

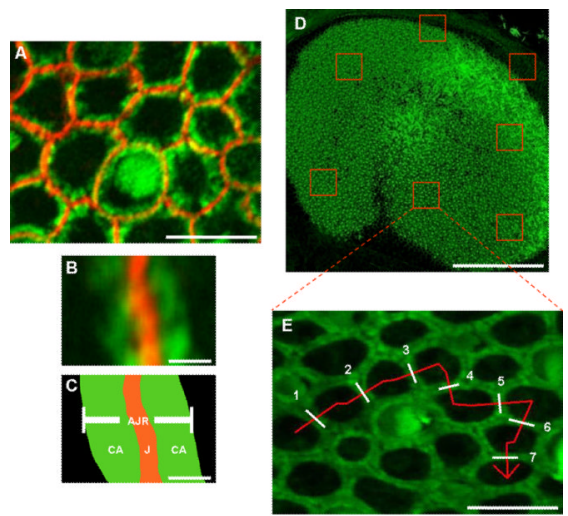

$\mathbf{F}$

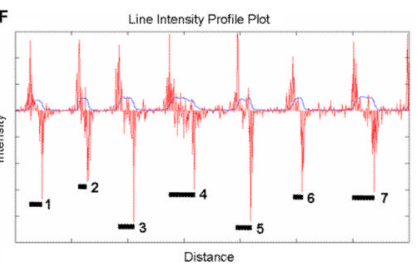

Figure 3.

The width of apical junction regions (AJRs) can be measured by plotting intensity profiles for lines drawn perpendicular to the junctions and analyzing them with a 1-D edge detector. A-C) An AJR was defined as the area containing the intercellular junction ( $J$ ) of adjoined supporting cells and the circumferential F-actin (CA) extending from both sides of the junction into the intracellular domain of each cell. Circumferential F-actin is shown in green, and $\mathrm{N}$-cadherin immunohistochemistry shows the junction in red. Scale bar in A, $5 \mu \mathrm{m}$; scale bar in B and C, $0.4 \mu \mathrm{m}$. D) Stacks of confocal images were collected of whole mount utricles stained with phalloidin. Scale bar, $150 \mu \mathrm{m}$. E) The stacks were converted to 2-D projections, and lines (red) were drawn perpendicular to the AJRs (designated by numbers and white bars). Scale bar, $10 \mu \mathrm{m}$. F) The 12-bit intensity values for each pixel in the lines were saved and plotted versus distance in Matlab R2007a (blue plot). The distance between the edges of local peaks on the intensity profile corresponded to the width of individual AJRs (numbers and black lines). The forward difference of the intensity profile, an approximation of the derivative, was calculated and plotted over the intensity profile (red plot). The intensity peak widths were then measured by calculating the distance between the local maxima and minima on the forward difference plot, which corresponded to the edges of each AJR. (A magenta-green version of this figure is provided in the supplementary material) 


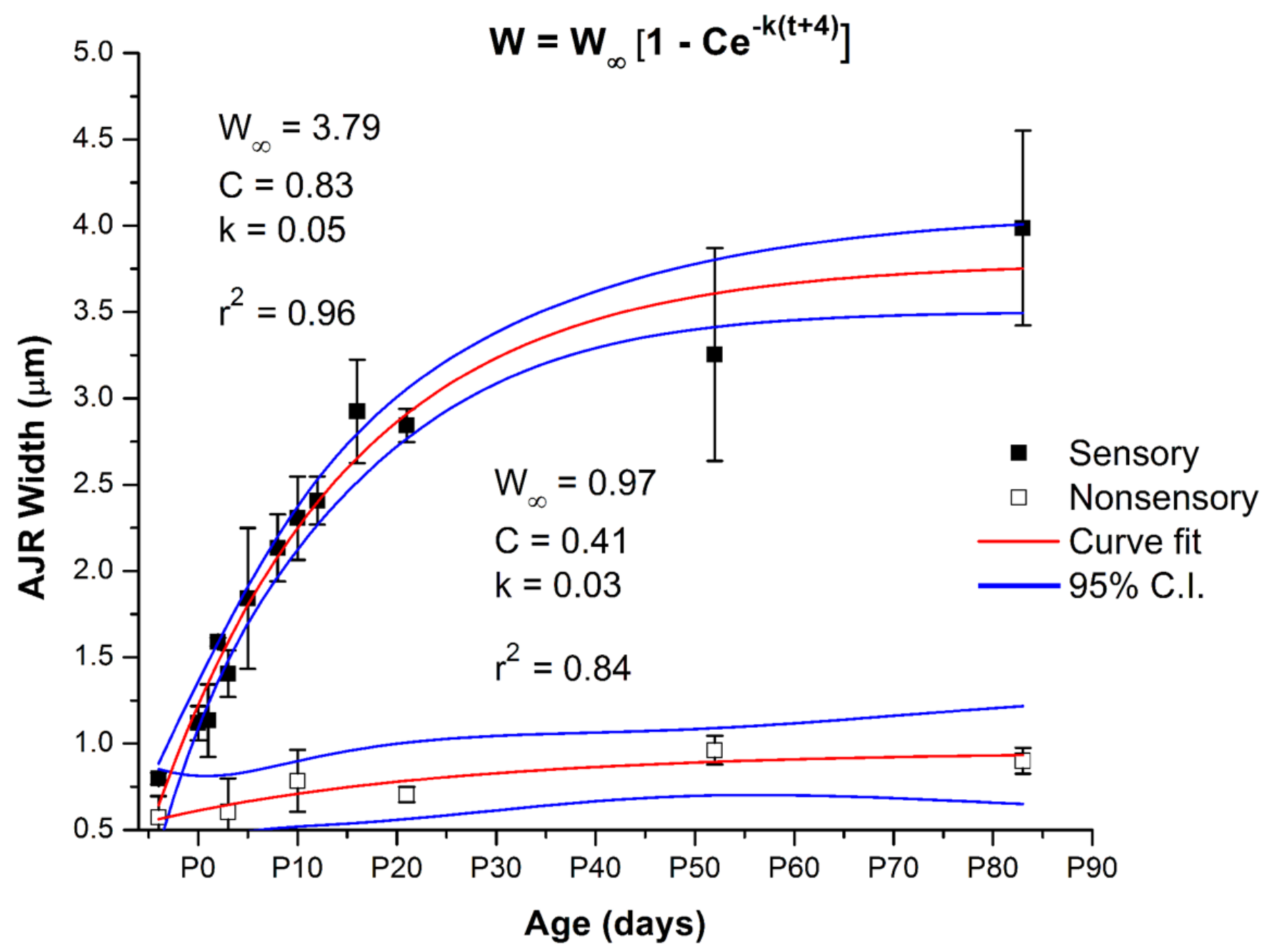

Figure 4.

Quantification of apical junction region (AJR) width shows there is exponential growth of AJRs in supporting cells of the sensory epithelium and cells of the nonsensory epithelium as mice develop and mature from embryonic day 18 (E18) to postnatal day 83 (P83).

Measurements of the width of AJRs from $\geq 400$ junctions in fifteen different age groups of mice for the sensory epithelium and six different age groups for the nonsensory epithelium were taken. AJR width increases $400 \%$ in the sensory epithelium (black squares) and $178 \%$ in the nonsensory epithelium (open squares). Von Bertalanffy growth curves (red lines) fit the data with high r-squared values, and the data points fall within the $95 \%$ confidence intervals (C.I.; blue lines). The parameters for the curve fits all had squared error values less than 0.2. W: AJR width; $\mathrm{W}_{\infty}$ : AJR width at infinity; $\mathrm{C}$ : scaling factor to prevent initial width from equaling zero; $\mathrm{k}$ : curvature parameter; $\mathrm{t}$ : time in days. 

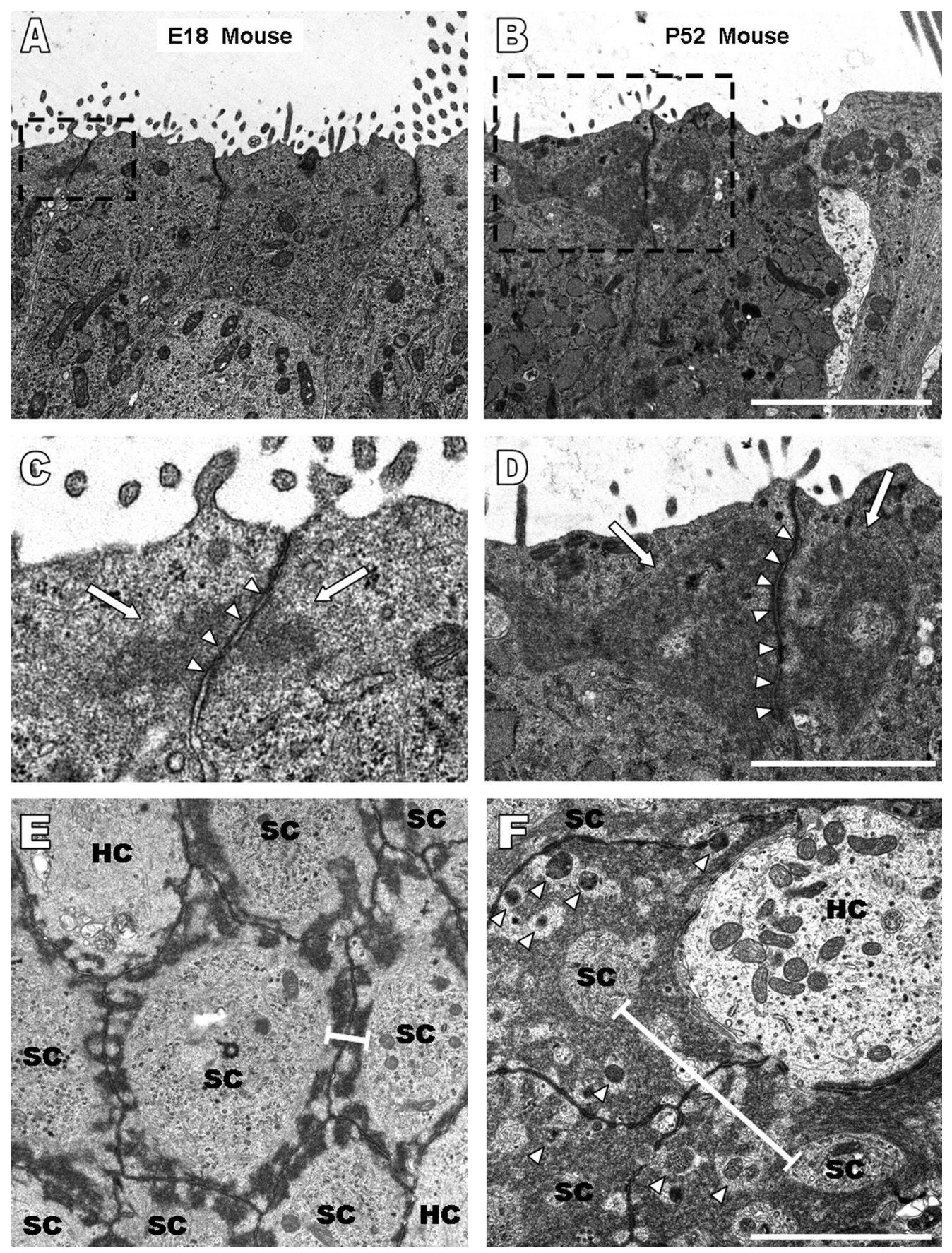

Figure 5.

Ultrastructural analysis of longitudinal and transverse sections of utricles from mice ranging in age from embryonic day 18 (E18) to postnatal day 52 (P52) demonstrate circumferential F-actin bands increase in width, not intercellular junctions; and there is a coinciding increase in the height of F-actin bands. A-B) Increases in the vertical dimension of circumferential Factin bands parallel to the lateral membrane are seen in longitudinal sections from an E18 and P52 mouse. Scale bar for A and B in B, $10 \mu \mathrm{m}$. C-D) High magnification images of the boxes outlined with black dashes in A and B show the intercellular junction (arrow heads) does not change in width while the F-actin bands extend further from the junction as mice age. Scale bar for C and D in D, $2 \mu \mathrm{m}$. E-F) Transverse sections from an E18 mouse (E) and 
a P52 mouse (F) provide a view identical to that seen in confocal images. Circumferential Factin bands (width shown by black bars) almost cover the entire apical planar area of the supporting cells by P52. The size of the intercellular junctions, however, remains the same at both ages. Vesicles (arrow heads) are visible in the F-actin bands in the transverse section from the P52 mouse. Scale bar for E and F in F, $2 \mu \mathrm{m}$. 


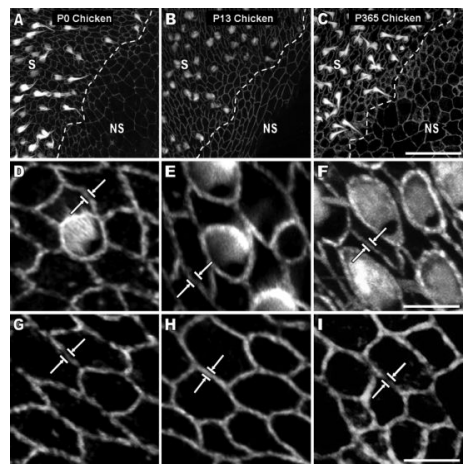

Figure 6.

The width of circumferential F-actin bands in utricular supporting cells of the sensory epithelium and cells of the nonsensory epithelium remains narrow throughout life in chickens. A-C) 2-D projections were taken of stacks of high resolution confocal images (63x 1.4 NA objective) from phalloidin-stained utricles of chickens at postnatal day 0 (P0), P13, and P365. The transition from sensory epithelium (S) to nonsensory epithelium (NS) shows that the width of $\mathrm{F}$-actin bands between these two regions apparently remains narrow as chickens age. Scale bar for A-C in C, $30 \mu \mathrm{m}$. D-I) Higher magnification images of the S and NS from the frames in A-C show that the bands (white arrows) remain within close spatial proximity to the junctions in both regions. Scale bar for D-F in F, $5 \mu \mathrm{m}$. Scale bar for G-I in $\mathrm{I}, 5 \mu \mathrm{m}$. 


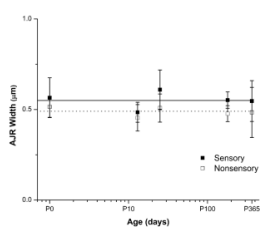

Figure 7.

Quantification of apical junction region (AJR) width shows there is apparently no growth of AJRs in supporting cells of the sensory epithelium and cells of the nonsensory epithelium as chickens develop and mature from postnatal day 0 (P0) to P365. The width of AJRs from $\geq$ 400 junctions from chickens from five different age groups was quantified. AJR width in supporting cells of the sensory epithelium (black squares; solid line is the average of all the age groups) and cells of the nonsensory epithelium (open squares; dotted line is the average of all the age groups) remains narrow throughout life ( $\mathrm{x}$-axis is on a logarithmic scale). 

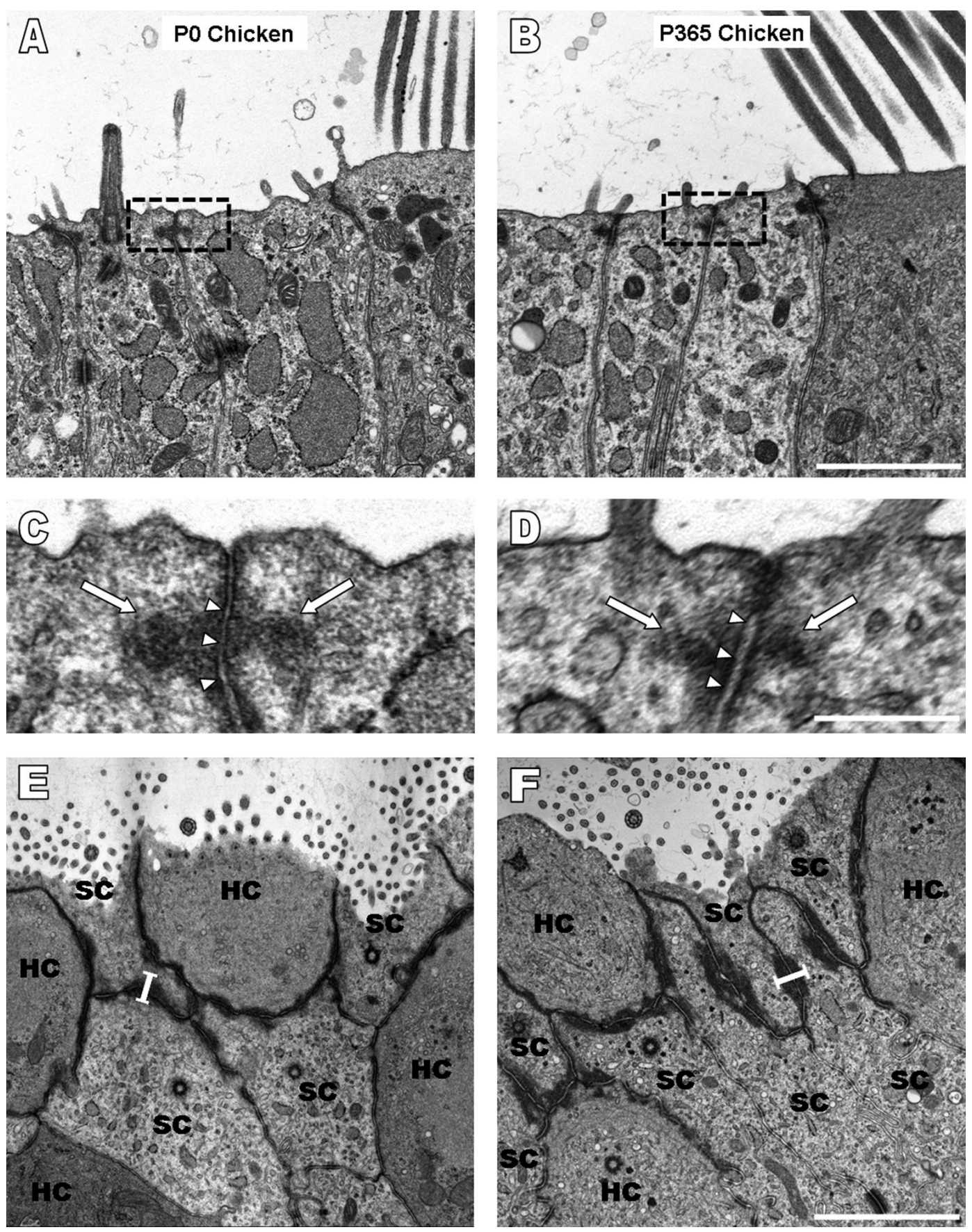

Figure 8.

Ultrastructural analysis of longitudinal and transverse sections of utricles from chickens ranging in age from postnatal day 0 (P0) to $\mathrm{P} 365$ demonstrates that circumferential F-actin bands remain narrow in the vertical dimension in addition to width. A-D) The vertical dimensions of F-actin bands (arrows in $\mathrm{C}$ and $\mathrm{D}$ ) at the adherens junctions (arrowheads in $\mathrm{C}$ and D) in TEM images of longitudinal sections from a P0 and P365 chicken are thin and comparable. Scale bar for A and B in B, $2 \mu \mathrm{m}$. Scale bar for C and D in D, $0.5 \mu \mathrm{m}$. E-F) Transverse sections provide a view identical to that seen in confocal images, and the width (black bars) of the F-actin bands in P0 (E) and P365 (F) chickens is similar. Scale bar for E and $\mathrm{F}$ in $\mathrm{F}, 2 \mu \mathrm{m}$. 
A

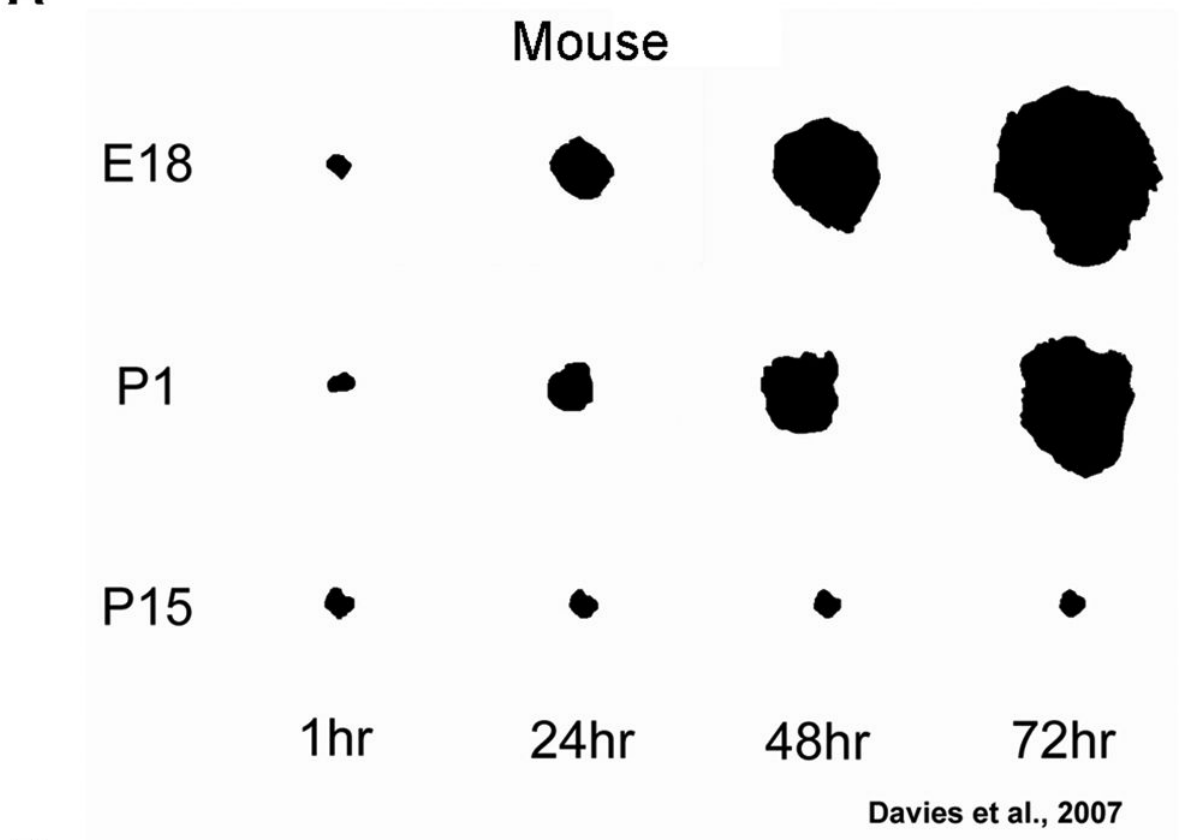

B

\section{Chicken}
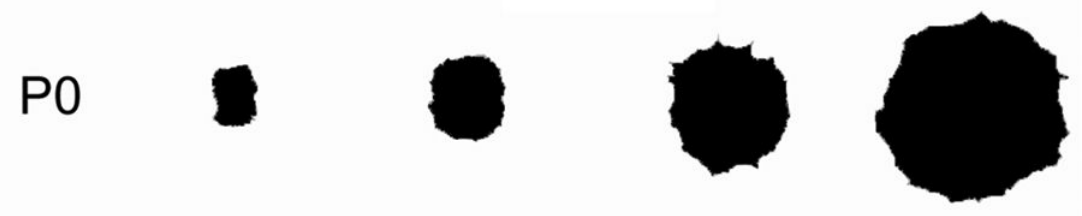

P60
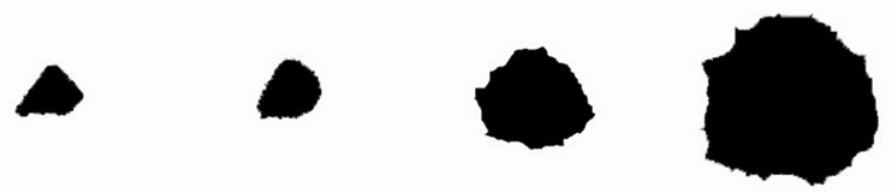

$\mathrm{P} 180$
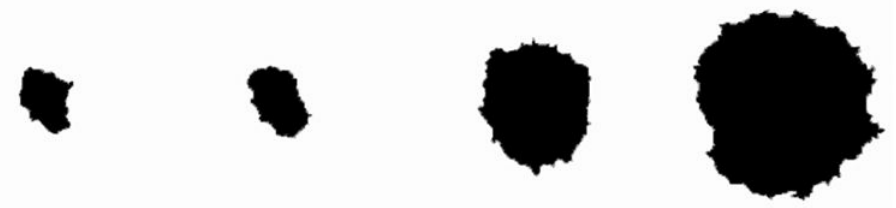

Figure 9.

The spreading of mammalian utricular epithelia gradually decreases with the age of the animal from which the tissue was harvested throughout the culture period, while the spreading of avian utricular epithelia occurs extensively and independently of the animal's age. A) Outlines of representative images of mammalian utricular sensory epithelia derived from embryonic day 18, postnatal day 1 (P1) and P15 mice at 1, 24, 48 and $72 \mathrm{hr}$ in culture illustrate the gradual reduction in tissue spreading with age (Davies et. al, 2007). B) Outlines of representative images of avian utricular sensory epithelia derived from P0, P60 and P180 chickens at 1, 24, 48 and $72 \mathrm{hr}$ in culture illustrate the age-independent extensive tissue spreading. Scale bar, $1 \mathrm{~mm}$. 
A

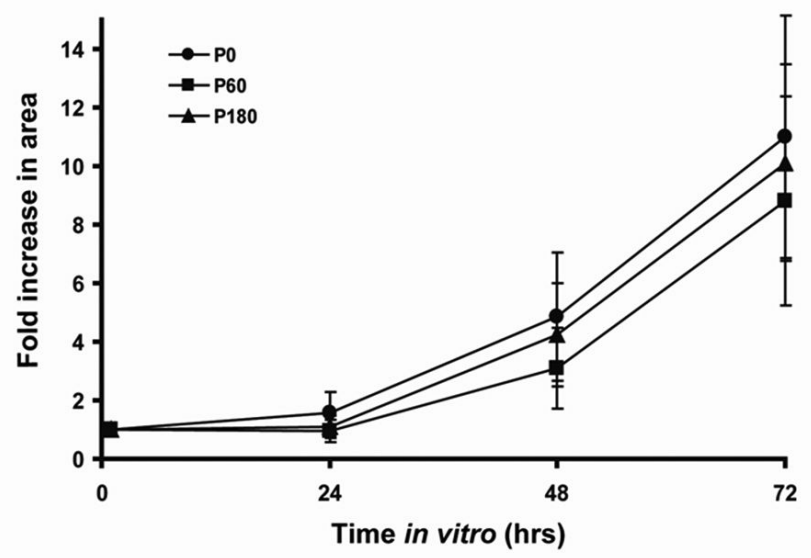

B

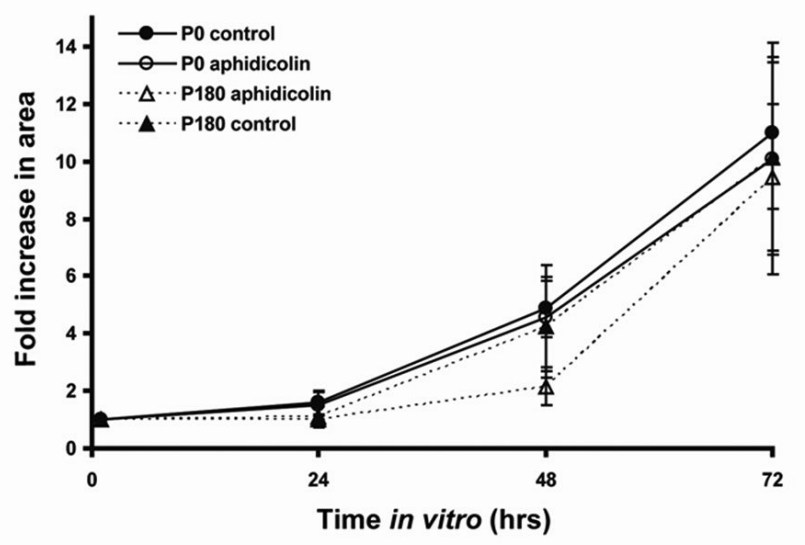

C

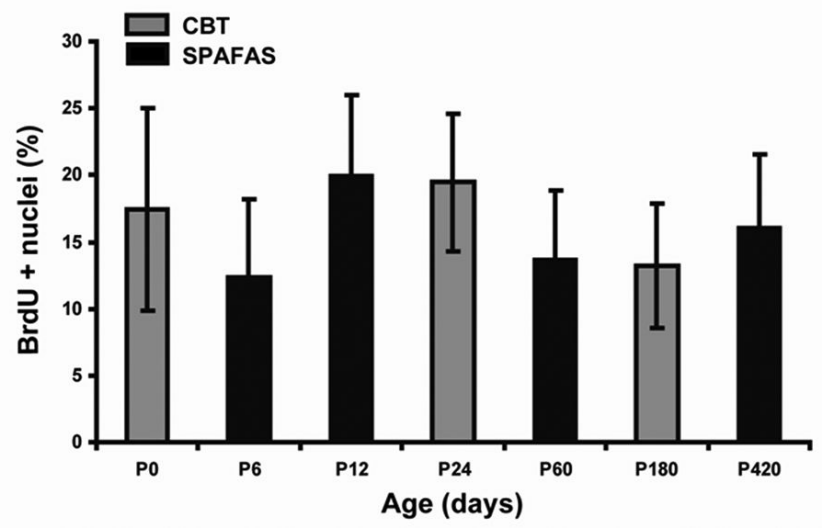

Figure 10.

The rate of spreading and proliferation of avian utricular epithelia on fibronectin (FN) is maintained at similar levels throughout life. A) Rates of spreading shown as fold increase in area throughout the culture period were similar in neonates (postnatal day $0(\mathrm{P} 0), \mathrm{n}=41$ sheets) and adult chickens (P60, n= 45 and P180, n= 44). B) Inhibition of cell division with the DNA polymerase inhibitor aphidicolin $(25 \mu \mathrm{M})$ yielded a similar degree of tissue spreading in utricular epithelial sheets from $\mathrm{P} 0$ ( $\mathrm{n}=9$ sheets) and $\mathrm{P} 180$ ( $\mathrm{n}=5$ sheets) chickens at 24,48 and $72 \mathrm{hr}$ in culture. C) S-phase entry after $72 \mathrm{~h}$ in culture shown as the percentage of BrDU positive cells was maintained at similar levels in chickens ranging in age from $\mathrm{P} 0$ to $\mathrm{P} 420$ (number of epithelia sheets analyzed; $\mathrm{P} 0, \mathrm{n}=27 ; \mathrm{P} 6, \mathrm{n}=27 ; \mathrm{P} 12, \mathrm{n}=26 ; \mathrm{P} 24, \mathrm{n}=23$; 
$\mathrm{P} 60, \mathrm{n}=24 ; \mathrm{P} 180, \mathrm{n}=27 ; \mathrm{P} 420, \mathrm{n}=11)$. CBT and SPAFAS are the names of the two different suppliers of chickens utilized in this experiment. 


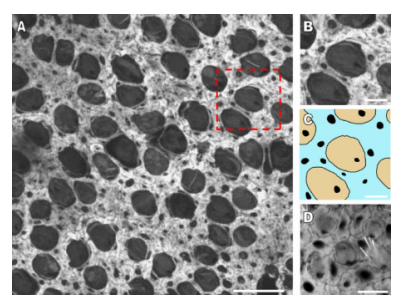

\section{Figure 11.}

The width of circumferential F-actin bands increases in the utricular supporting cells of developing humans and other murine balance organs. A) A high resolution confocal image of the sensory epithelium of a utricle stained with phalloidin from a 60 year-old human cadaver shows the extent to which the F-actin bands cover supporting cell apical areas. Scale bar, $15 \mu \mathrm{m}$. B and C) A zoomed in region of the sensory epithelium (box outlined with red dashes in A) shows the location of the bands in supporting cells (blue) in relation to the cuticular plates of hair cells (tan). Very little area remains free of F-actin in the supporting cell apical areas. Scale bar in B and C, $5 \mu \mathrm{m}$. D) A high resolution confocal image of the sensory epithelium in the cristae ampullaris from a postnatal day 120 mouse shows that the circumferential F-actin bands of supporting cells have almost an identical morphology to that seen in the utricles of adult mice. Scale bar, $5 \mu \mathrm{m}$. 

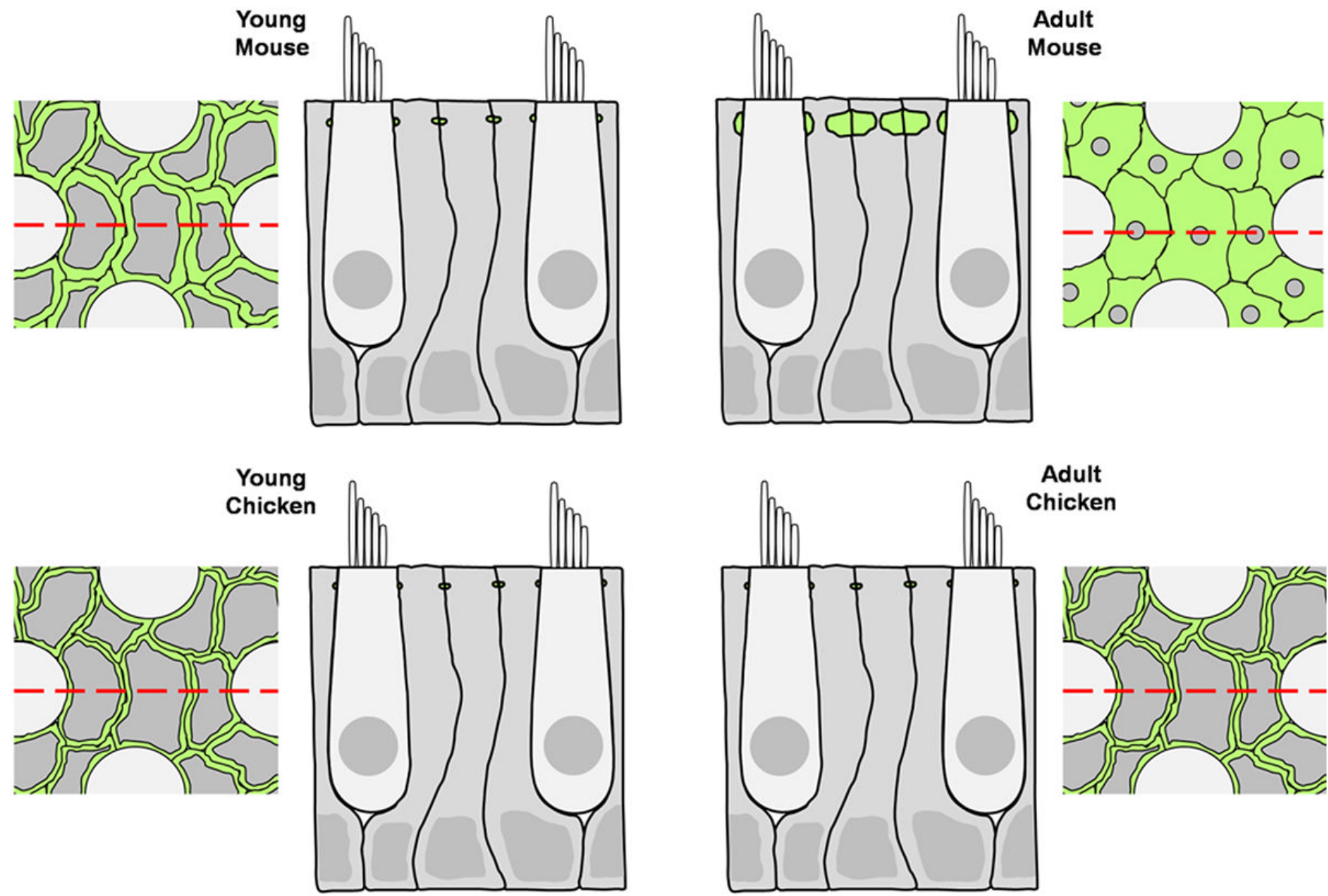

Adult

Chicken

Figure 12.

A schematic of transverse and longitudinal sections through the utricular sensory epithelium compares the thickness of circumferential F-actin bands in chickens of all ages, immature mammals, and adult mammals. F-actin is colored green, supporting cells are colored gray, and hair cells are colored light gray. The red dashed lines on the transverse sections correspond to the location of the longitudinal sections. 


\section{TABLE 1}

Mean widths of apical junction regions in murine utricular epithelia

\begin{tabular}{lcccc}
\hline & \multicolumn{2}{c}{ Sensory Epithelium } & & \multicolumn{2}{c}{ Nonsensory Epithelium } \\
\cline { 2 - 3 } Age & Mean Width $(\boldsymbol{\mu m})$ & SD $( \pm)$ & $\begin{array}{c}\text { Mean Width } \\
(\boldsymbol{\mu} \mathbf{m})\end{array}$ & SD $( \pm)$ \\
\hline E18 & 0.80 & 0.03 & 0.57 & 0.12 \\
P0 & 1.12 & 0.10 & - & - \\
P1 & 1.13 & 0.21 & - & - \\
P2 & 1.60 & 0.02 & - & - \\
P3 & 1.41 & 0.13 & 0.60 & 0.19 \\
P5 & 1.84 & 0.41 & - & - \\
P8 & 2.13 & 0.19 & - & - \\
P10 & 2.31 & 0.24 & 0.78 & 0.18 \\
P12 & 2.41 & 0.14 & - & - \\
P16 & 2.92 & 0.30 & - & - \\
P21 & 2.84 & 0.10 & 0.71 & 0.04 \\
P52 & 3.25 & 0.62 & 0.96 & 0.08 \\
P83 & 3.99 & 0.56 & 0.90 & 0.08 \\
\hline
\end{tabular}

AJR: apical junction region; E: embryonic day; P: postnatal day; SD: standard deviation 
TABLE 2

Mean widths of apical junction regions in avian utricular epithelia

\begin{tabular}{lccccc}
\hline & \multicolumn{2}{c}{ Sensory Epithelium } & & \multicolumn{2}{c}{ Nonsensory Epithelium } \\
\cline { 2 - 3 } Age & $\begin{array}{c}\text { Mean Width } \\
(\boldsymbol{\mu})\end{array}$ & SD $( \pm)$ & $\begin{array}{c}\text { Mean Width } \\
(\boldsymbol{\mu m})\end{array}$ & SD $( \pm)$ \\
\hline P0 & 0.56 & 0.11 & 0.51 & 0.06 \\
P13 & 0.48 & 0.05 & 0.45 & 0.07 \\
P25 & 0.61 & 0.11 & 0.51 & 0.08 \\
P180 & 0.55 & 0.04 & 0.48 & 0.04 \\
P365 & 0.55 & 0.11 & 0.48 & 0.14 \\
\hline
\end{tabular}

AJR: apical junction region; P: postnatal day; SD: standard deviation 